Portland State University

PDXScholar

Dissertations and Theses

Dissertations and Theses

1985

\title{
Juvenile delinquency in Saudi Arabia
}

Yousef Ahmed AlRomaih

Portland State University

Follow this and additional works at: https://pdxscholar.library.pdx.edu/open_access_etds

Part of the Juvenile Law Commons, Near and Middle Eastern Studies Commons, and the Social Control, Law, Crime, and Deviance Commons

Let us know how access to this document benefits you.

\section{Recommended Citation}

AlRomaih, Yousef Ahmed, "Juvenile delinquency in Saudi Arabia" (1985). Dissertations and Theses. Paper 3423.

https://doi.org/10.15760/etd.5302

This Thesis is brought to you for free and open access. It has been accepted for inclusion in Dissertations and Theses by an authorized administrator of PDXScholar. Please contact us if we can make this document more accessible: pdxscholar@pdx.edu. 
AN ABSTRACT OF THE THESIS OF Yousef Ahmed AlRomaih for the Master of Arts in Sociology presentea November 15, 1985.

Title: Juvenile Delinquency in Sauāi Arabia. APPROVED BY MEMBERS OF THE THESIS COMINITTEE:
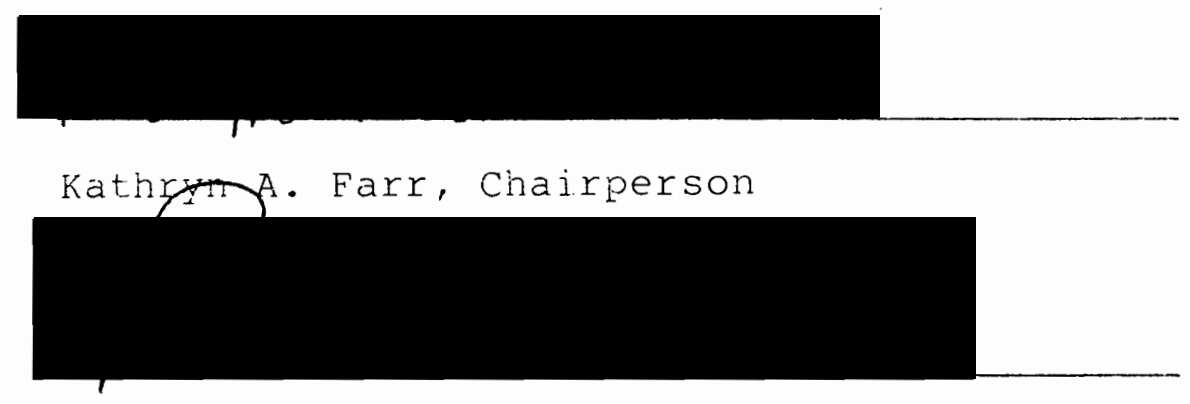

Robert W. Shotola

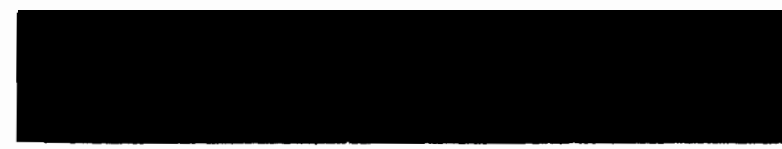

Grant M. Farr

Juvenile delinquency has recently been officially recognized in Saudi Arabia as a problem in need of response. The Saudi. Arabian government has begun to respond to juvenile misconduct by developing institutional services for juveniles. However, there is at present very little social scientific research of either a descriptive or analytical nature on delinquency in Saudi Arabia.

The present study involved an examination of the delinquency problem in Saudi frabia within the framework of social control theory. Specifically, the study was based on the thesis set forth by Travis Hirschi, i.e., that 
delinquent acts result when an individual's bond to society is weak or broken. Also taken into account, however, were the finaings from the research of wiatrowsin, et al. that suggest a need for a) some modifications in Hirschi's conceptual framework and i) inclusion of socio-economic factors in the social control model.

A questionnaire including items used by Hirschi and by wiatrowski, et al. was administered to four groups of male Saudi Arabian juveniles: stuàents attenảing a public high school ( $\mathrm{N}=129)$, students attending a junior high school $(N=58)$, juveniles incarcerated in an institution for serious offenders $(N=150)$, and juveniles incarcerated in an institution for status offenders $(N=96)$. The schools and the institutions were all located in the capital city of Riyadh. One measure of the dependent variable, i.e., juvenile delinquency, was obtained by asking all respondents to report on the nature and extent of their involvement in delinquency. In addition to this self-report measure, a measure of official delinquency was built into the research design with the inclusion in the sample of populations of incarcerated delinquents as well as "normal" school students. Thus, assessments could be made of the contribution of the independent variables--social bond and social background items--to the variance in incarceration for delinquency and to the variance in actual involvement in delinquency. Comparisons were also macie of the four sub-groups in the study sample. 
Findings from a factor analysis of the social bond items raisea questions about Hirschi's suggestion that the bond consists of four elements--attachment, belief, commitment and involvement. Ten (ratiner than four) factors were identified in a varimax rotated factor structure. For the most part, variables with high loadings on each of these factors emphasized one or more elements of the bond within a specific institutional area, e.g., commitment to school, attachment to parents, belief and involvement in religion.

Social bond items explained $27 \%$ of the variance in incarceration and $26 \%$ of the variance in self-reported delinquency. The predictive power of the model was strengthened by including socio-economic variables. However, socio-economic variables better predicted incarceration for delinquency than self-reported delinquency. Incarceration was most strongly correlated with negative school attitudes and welfare recipiency. "Pray," the factorderived measure of religious bond, was also negatively correlated with incarceration for delinquency. Weak school commitment and weak religious belief/involvement best predicted self-reported involvement in delinquency.

While the majority of respondents in all four groups appeared to have strong social ties with conventional society, incarcerated offenders were less strongly bonded than public school students. Juveniles in the institutions for serious offenders had the weakest bond of all four groups. 
JUVENILE DELINQUENCY IN SAUDI ARABIA

\author{
by \\ YOUSEF AHMED ALROMAIY
}

A thesis submitted in partial fulfillment of the requirements for the degree of

\author{
MASTER OF ARTS \\ in \\ SOCIOLOGY
}

PORTLAND STATE UNIVERSITY
1985 Yousef Ahmed AlRomain 
TO THE OFFICE OF GRADUATE STUDIES AND RESEARCH:

The members of the Committee approve the thesis of Yousef Ahmed AlRomaih presented November 15, 1985.

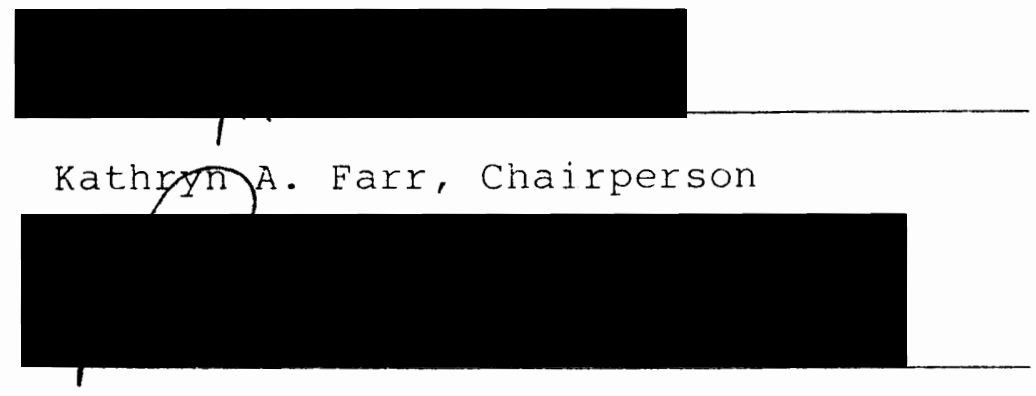

Robert $W$. Shotola

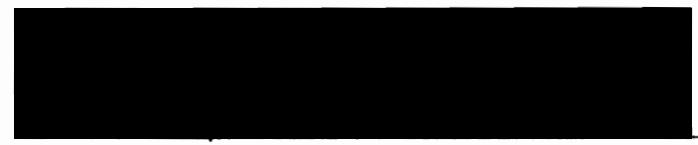

Grant M. Farr

\section{APPROVED :}

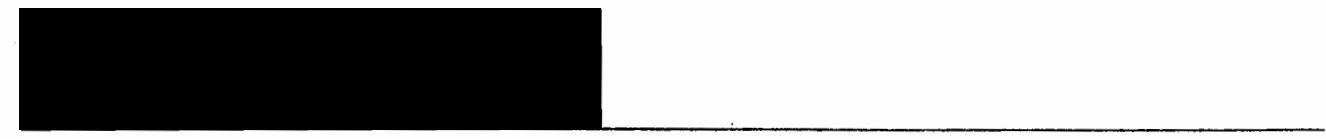

Grant M. Farr, Head, Department of Sociology

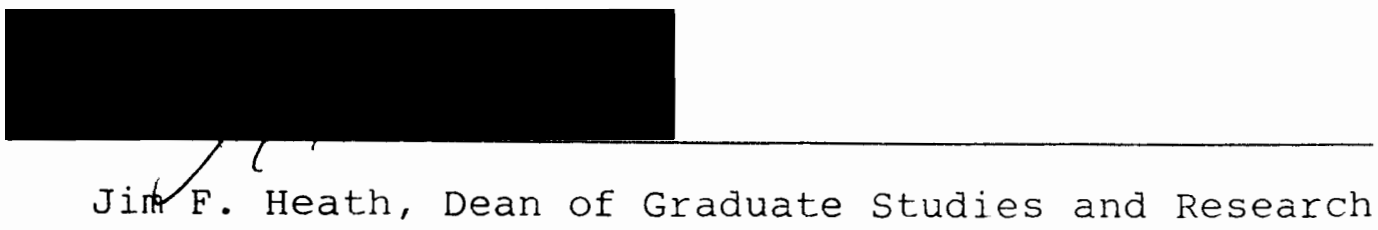




\section{ACKNOWLEDGEMENTS}

First, it would have been impossible to complete this project without the support of the Saudi Arabian government. Secondly, I would like to express very deep gratitude to my committee as a whole. In a very real sense, this research would have been impossible without their support and encouragement. Third, I must thank specifically Dr. Kathryn A. Farr, the chairperson of this thesis committee, for the many hours of instruction and discussion she shared with me. During the many hours of this project, I always found her extremely patient and kind as well as generous with her guidance and wisdom. Finally my thanks goes to my family and friends here in portland and those in Saudi Arabia. 
TABLE OF CONTENTS

PAGE

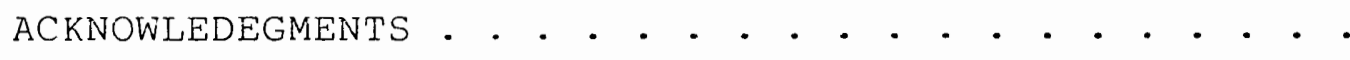

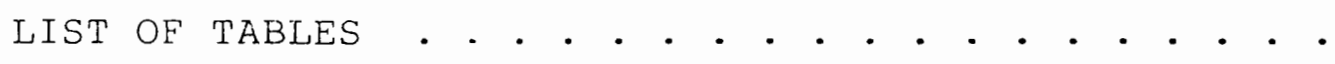

CHAPTER

I INTRODUCTION . . . . . . . . . . . . . . 1

Statenent of Problem . . . . . . . 1

Review of the Literature . . . . . . 4

Hirschi's Control Theory . . . . . . 7

II METHODOLOGY . . . . . . . . . . . . . 12

Subjects.............. . . . 18

Data Analysis . . . . . . . . 21

II DELINQUENCY IN SAUDI ARABIA: FINDINGS

AND ANALYSES . . . . . . . . . . . 22

Frequency Distribution . . . . . . 22

Age Distribution . . . . . . . 22

Self-Report Delinquency . . . . . . 23

Social Background Characteristics . . 25

High Bond, By School-Related Items . . 28

High Bond, By Friend-Related Items . . 31

High Bond, By Religion-Related Items . 32

High Bond, By Job-Related Items . . 34

High Bond, By Family-Related Items . • 35

High Bond, By Miscellaneous Items . . 36 
PAGE

An Examination of tine Social Bond Concept

Through Factor Analysis . . . . .

Factor Analysis of Self-Report

Delinquency and Social Background

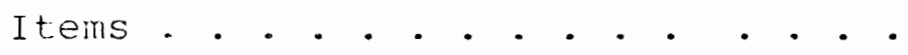

Correlations with DLNQSUiv,

BY Groups • . • . . . . . . . . .

Correlations Between Social Bond Items,

Incarceration aná DLNQSUM . . . . .

Correlations Between Soc Backgrouna

Items, Incarceration and DLNQSUM .

Stepwise Multiple Correlations:

Independent Variables By Incarceration

and DLNQSUM . . . . . . . . . . .

Stepwise Multiple Correlations:

Independent Variables BY DELPERS

and DELPROPS . . . . . . . . . . .

IV

SUMMARY AND CONCLUSION 


\section{LIST OF TABLES}

I Age Distribution . . . . . . . . . . •

I Percentage of Sub-Groups Reporting High

Involvement In Delinquency, By

Offense • • . • • . . . . . . • .

II Social Background Characteristics of SubGroups, Percent Agreeing . . . . . .

Percentage of Sub-Groups Reporting High

Bond, By School-Related Items . . . .

$\mathrm{V}$ Percentage of Sub-Groups Reporting High

Bond, By Friend-Related Items . . . .

VI Percentage of Sub-Groups Reporting High

Bond, By Religion-Related Items . . .

VII Percentage of Sub-Groups Reporting High

Bond, By Job-Related Items . . . . .

VII Percentage of Sub-Groups Reporting High

Bond, By Family Attachment . . . . . 35

IX Percentage of Sub-Groups Reporting High

Bond, By Miscellaneous Items . . . 36

X Varimax Rotated Factor structure . . . . 40

XI Correlation With DLNQSUM, By Groups . • . 46

XII Correlations Between Social Bond Items, 
XIII Correlations Between Soc Background Items, Incarceration ana DLNQSUM . . . . . . . 54

XIV Stepwise Multiple Correlations: Independent Variables By Incarceration and DLNQSUM • • • • • • • • • • • • • • • . 55 XV Stepwise Multiple Correlations BY DELPERS and DELPROP • • • . . . . . . . . . 
CHAPTER I

\section{INTRODUCTION}

Saudi Arabia is located in southwest Asia in the middle of the Arabian Peninsula which includes Saudi Arabia, Yemen, Kuwait, united Arab Emerates and gatar. It covers an area of about two million square kilometers (about nine hundred thousand square miles). The population of Saudi Arabia is more than eight million people. The modern nation of Saudi Arabia was established by King Abdulaziz Ibn Saud in 1932. The criminal justice system in Saudi Arabia is based primarily on Sharia, which means that all laws in society are taken from the Quran (the Muslim holy book revealed by God to the messenger Muhammad [peace be upon him] in the sixth century after christ). The second source of law in Saudi Arabia is Sunnah, which elaborates what prophet Muhammad said or did. It supplements the Quran and provides an explanation of its verses. The Sunnah contains the teachings of the Prophet Muhammad which are to be used by each Muslim as a model in his/her daily life.

There have been great social changes taking place in Saudi Arabia for the last thirty years. The country has been going through extensive development, which is bringing changes in families and tribal groups. Modernization has resulted in an increase in secondary group relationships in 
which people hardly know each other and are not bound by affectional ties. The traditional communities are breaking down. people are migrating to the urban centers following the oil-created jobs. The extended families are changing their life style and are fast becoming replaced by nuclear families. Consequently, socio-economic classes are emerging more clearly. Many immigrants are coming from all over the world looking for well paid jobs. They have introduced into Saudi Arabia cultural values that are new and different. During periods of rapid social change, societies are typically confronted with new social problems. One such problem in Saudi. Arabia is juvenile delinquency. The purpose of this thesis is to identify some of the causes and correlates of delinquency in contemporary Saudi Arabian society.

Delinquency in Saudi Arabia was not officially recognized until 1954, when the first status offenders' school was established in Riyadh, the capital city. During the first years, the population of the institution ranged from five to ten juveniles.

In 1972 the first institution for serious juvenile offenders was established in Riyadh. Today, juvenile institutions in Saudi Arabia can be classified as one of these two types--institutions for status offenders (Type B) or institutions for criminal offenders (Type A). (For detailed description of the two institutions see pages 17 and 18.$)$ 
In Saudi Arabia today there are four Type A institutions, all located in the major cities. Also, there are five Type $B$ institutions located in the same cities, and one located in a medium-sized city. Today hundreds of juveniles pass through these two kinds of institutions each year. Saudi Arabia still has a very low rate of crime and delinquency. According to the oregonian newspaper in an article published last year, "Saudi Arabia is probably the most crime free country in the world on a per capita basis." (Feb. 1984:4). In comparison to some neighboring Arab countries, we see that Saudi Arabia has the lowest crime rate. In 1978 the crime rate in Saudi Arabia was .696 (for each thousand people in the population), while in Kuwait it was 2.16, in Syria it was 1.694, and in Libya it was 2.943 for the same year (Ministry Interior Publication, 1978).

Today there is little social scientific research of either a descriptive or analytical nature on delinquency in Saudi Arabia. The present study is an attempt to shed further light on the delinquency problem in Saudi Arabia within the framework of social control theory. Specifically, the study is based on the thesis set forth by Travis Hirschi--that delinquent acts result when an individual's bond to society is weak or broken (Hirschi, 1969:16).

I chose this particular theory to be used for this study because I felt very strongly that it emphasized the sources of social control which have been particularly 
effective in maintaining conformity in Saudi Arabia. As I said earlier, my country has been going through a number of social changes and developments that have affected family structure and, in turn, the relationship between child and parent. Also, the bond theory fits well because of the importance in Saudi Arabian culture of the belief in and commitment to conventional institutions, such as school, work, and religion.

The Social control Perspective

One of the earliest pioneers in the area of social control was Emile Durkheim (1897), who discussed the relationship between an individual and society. When the relationship is weak the individual starts depending on him/herself rather than the society; as a result he/she starts constructing his/her own norms, rejecting the norms of society, and accepting what fits personal needs only. Utilizing a functional perspective, Durkheim argued that in societies characterized by low social solidarity, social control could not be eifectively generated. The result was social instability and individual deviance.

Another pioneer, E.A. Ross (1901), directed considerable attention to the ways in which social control contributed to societal stability. Ross shared with Durkheim the view that harmony and consensus were essential for the maintenance of social control. In his later writings, however, Ross reconsidered the role of consensus in effecting 
social control. His description of the ways in which social control mechanisms frequently reflected special interests of elite groups accompanied his growing suspicion that social control dia not always represent values shared by the public. Ross' empiasis on social control as an outgrowth of class and power struggles served as a forerunner for the developinent of the conflict perspective on social control. Social psychologists Charles H. Cooley (1902) and George H. Mead (1925) offered still another point of view on social control. Cooley and Mead shifted the picture from shared consensus to the interaction process. Both believed that social control was maintained by self control, the latter brought about by the internalization of the norms and values of society. Socialization was an important concept for Mead and Cooley because it was through this early interaction with significant others (i.e., parents and other direct role models) that the internalization of social expectations began to take place. Cooley used the term "looking glass self" to describe the process through which the individual acquires a self in accordance with the reactions and responses of others to him or her. According to Mead, the individual moves from taking the role of significant others to internalizing the expectations of the generalized other (i.e., a reflection of the society or community in which the person lives). Social control, then, is a function of self control, which, in turn, is a function of social interaction. 
one of the earliest efforts to examine juvenile delinquency from a control perspective is found in the work of Walter Reckless. Reckless (1973) argued that juveniles reErained from delinquency due partially to outer containment (ties to society such as effective family life, living in a community which still retains an interest in the activities of its members) and partially to inner containment (positive self attributes such as self-control, good self-concept, high sense of responsibility, goal orientation, tensionreducing rationalization). This theory could be applied to the treatment of delinquency in a variety of ways. For example, inner containment might be enhanced by building up ego strength, developing new goals, and internalizing new models of behavior. Outer containment could be improved by strengthening existing social ties and creating new anchors and supportive relationships. Reckless also talked about pulls and pushes toward delinquency. Internal pushes involved such factors as mental conflict, rebellion, and anxieties. External pulls could be represented by deviant companions or criminal subcultures. Additionally, external pressures such as poverty and unemployment could lead to delinquency. Thus, at the same time that people have innerouter containment to prevent them from going into crime, they also have internal and external pulls and pushes that draw them into criminality.

Reckless questioned 125 young males in columbus, ohio. He picked boys who defined themselves and were defined by 
others as "good boys." He compared them to those who defined themselves and were defined by others as "bad boys." Reckless and his associates found that deviant images were highly correlated with criminal activities. Although Reckless' study was criticized for its methodology in such areas as sampling, measurement and definitions of delinquency, it did identify possible links between personal and social controls and involvement in delinquency.

\section{Hirschi's Control Theory}

In 1969 Travis Hirschi wrote Causes of Delinquency, in which he elaborated in aepth his theory of the relationship between social control and delinquency.

The basic question Hirschi's control theory is trying to answer is, as Hirschi himself put it, "In the end then, control theory remains what it has always been: a theory in which deviation is not problematic. The question "Why do they do i.t?' is simply not the question the theory is designed to answer. The question is "Why don't we do it?' There is much evidence that we would if we dared." (Hirschi, 1969:34). So Hirschi, as a control theorist, differed from other theorists of criminality by asking Hobies's question, not answering it. Control theorists see all people as potential law breakers. Hirschi's theory sought an answer to the question of why people obey the law. 
Hirschi's argument is that delinquent acts result when an individual's bond to society is weak or broken (Hirschi, 1969:16). The bond is made up of four elements:

1. Attachment: ties between the juvenile and significant others, such as, parents, peers, and teachers.

2. Commitment: adherence to conformist aspirations and goals, such as going to college and attaining a high status job.

3. Involvement: participation in conventional activities.

4. Belief: acceptance of the legitimacy of conventional activities, norms, and the value system of society. Hirschi tested his theory on a sample of over four thousand students drawn from the 17,500 students entering the 11 public junior and senior high schools in Richmond, California, in the fall of 1964. The data used in his study came from several sources: (1) school records providing information on student characteristics such as grades, sex, race and academic achievement; (2) a lengthy self-report questionnaire measuring elements of the bond and juvenile misconduct; (3) police records containing information on students' involvement in delinquency. While examining elements of the social bond, Hirschi also tested the interrelationships among elements; for example, if a person has a high attachment level, he/she should have a high commitment level, etc. 
Siegel (1983) has reported some of the major findings from Hirschi's study:

1. Juveniles who have a high level of attachment to their parents are unlikely to commit delinquent acts.

2. Both delinquent and non-delinquent juveniles share similar beliefs about society.

3. Commitment to conventional values, such as studying hard to get a good education, is related to conventional behavior.

4. Juveniles who are involved in conventional activities such as doing homework are less likely to get into criminal acts, whereas juveniles who are involved in unconventional activities such as drinking are more likely to commit criminal acts.

5. Delinquent juveniles have weak and distant relationships with significant others. Non-delinquent juveniles are attached more to their peers.

Hirschi's research, then, supported his social control theory. His findings, while explaining only a limited portion of the variance, were consistent with the basic theory. Subsequent research has been conducted to test the bond theory. One of the more important studies was that done by Michael Hindelang (1973). Hindelang studied male and female students from a rural area in New York. Students from grades six through twelve of one school were asked to complete a self-report questionnaire similar to the one used by Hirschi. Hindelang was able to replicate most of Hirschi's 
resuits with one major difference. Hindelang found in his sample that attachment between juveniles and their peers was directly related to delinquency, while Hirschi's finding was in the opposite direction.

Research by Raymond Eve (1975) found some support for Hirschi's social bond model, as compared to the "strain" and "culture conflict theories" as explanations of delinquency. Eve found that high levels of social control were related strongly to lower levels of drug use, but less strongly related to lower levels of traditional deviance (staying out late, etc.). In another study, Eve and Jensen (1976) found that a strong relationship between parents and children can prevent children from going into delinquency.

Michael D. Wiatrowski, et al.(1981) conducted a study that confirmed many of Hirschi's findings. This research showed that variables which were related to school (such as attachment, commitment, and involvement in school activities) were strongly related to delinquency. This study also indicated the importance of socio-economic class in explaining delinquency, a finding which led wiatrowski to develop a refined model of Hirschi's initial theory.

This thesis is a follow up to the work of Hirschi and his successors, with two major differences. First, the study was done in Saudi Arabia and thus allows for a crosscultural analysis of social control theory. Second, this study examines the relationship between social bond and 
delinquency for three populations of Saudi Arabian juveniles--juveniles incarcerated in a Type A institution (serious offenders); juveniles incarcerated in a Type B institution (status offenders); and juveniles attending public schools. 
CHAPTER II

\section{METHODOLOGY}

This research project was designed to examine juvenile delinquency in Saudi Arabia. I used the framework of social control theory with the emphasis on Hirschi's bond theory. The research procedure involved a cross-sectional survey of Saudi Arabian male juveniles ranging in age from 9 to 20. Questionnaire data were collected in February and March of 1985, in Riyadh, the capital city of Saudi Arabia.

A six page self-report questionnaire was constructed using items from Hirschi (1969) and wiatrowski, et al. (1981) measuring elements of the bond, delinquency acts and social characteristics. The items used included those which, based on a prior factor analysis, loaded most highly on specific elements of the bond (Wiatrowski, et al., 1981).

Some alterations and additions were made to enhance cultural relevance (e.g., "Do you pray every time at the Mosque?" as an indicator of involvement). Also, some items were left out because they were culturally inappropriate (e.g. "How often do you go out on dates?" as an indicator of attachment). For the questionnaire in its entirety, see Appendix A. 
Dependent Variable

A. Involvement in delinquency, the dependent variable, was measured by both type and frequency of selfreported misconduct. This part of the questionnaire covered the spectrum of activities ranging from status offenses (e.g. "Have you ever stayed out at night later than your parents said you should?" and "Have you ever defied your parents openly?") to property and personal crimes of varying severity (e.g., "Have you ever taken something not belonging to you worth over 200 Saudi Riyal?" and "Have you ever used a knife or any other thing like a club to get something from a person?"). Because it increasingly accounts for a large number of juvenile arrests in Saudi Arabia, "burning rubber in a car" was added to the list of offenses about which the juveniles were questioned. Respondents were asked to indicate theix involvement in each of these offenses by placing a checkmark in one of four categories: "no, never," "once or twice only," "sometimes," and "often."

An official measure of delinquency was built into the research design with the selection of two populations of institutionalized offenders as study groups. Comparisons were made between these official delinquent populations and samples drawn from students attending a public high school and a public junior high school in the capital city of Riyadh. In the final analysis, it was possible to determine the best predictors of self-reported delinquency as well as the best predictors of official delinquency. 
Independent Variables

Social bond elements, independent variables, were measured with items from both Hirschi (1969) and wiatrowski, et a1., (1981).

A. Attachment is ciefinea as the ties between the juvenile and significant others, such as parents, peers, and teachers.

B. Commitment is defined as the adherence to conformist aspirations and goals, such as going to college and attaining a high status job.

C. Involvement is defined as participation in conventional activities such as doing more school work and praying in the Mosque.

D. Belief is defined as acceptance of the legitimacy of conventional activities, norms and the value system of society

Following is a list of i.tems assumed to measure each element of the bond. Both the item source and whether or not the item has been shown to load highly in the factor analysis by wiatrowski et al., (1981) are also indicated. 
A. Attachment

source

Indicator *

of Loading

1. How close do you feel to your

Wiatrowski father?

2. How close do you feel to your mother?

3. How much do you want to be like your father when you are an adult?

4. How important woula you say friends are in your life?

Wiatrowski +

Hirschi

Wiatrowski +

5. How do you rate yourself in school ability compared with

Hirschi

those in your grade at school?

6. How close do you come to doing

wiatrowski

the best work you are able to do in school?

7. I feel satisfied with school because I learn things I want to know.

8. I believe school will help

Wiatrowski + me be a mature adult.

Wiatrowski

9. School is very boring for me, and I'm not learning what $I$

wiatrowski feel is important.

10. I feel the things I do at school wiatrowski waste my time more than the things I do outside of school.

11. I am studying constantly in order wiatrowski to become a well-educated person.

12. My teachers often take an interest in my work.

Hirschi

+ indicates factor minimal loading of + or - .365.

- indicates lower than .365 or that variable has not been subjected to a factor analysis. 
B. Commitment:

Source

Indicator

of Loading

1. Have you decided on a particular

Hirschi

kind of job you aim to do when

you have finished your schooling?

2. Write the name of the job you

Hirschi want to do.

3. It's likely that I will

Hirschi

attend college.

C. Involvement

1. When you are at home, ao you

pray every time at the Mosque?

Romain

2. I am very interested in doing more reading or work than my studies require.

3. Do you ever feel that "there is nothing to do."

Hirschi

Wiatrowski +

D. Belief

1. When you are at home, do you

Romain

pray every time at the Mosque?

2. If you don't pray, what will be

Romaih

the reaction of your parents?

3. It's bad to cheat or have anything to do with a cheating situation, even for a friend.

4. I would help a close friend get by in a tight situation, even

Wiatrowski + though I may have to stretch the truth a bit.

Wiatrowski

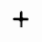

I have used a Likert scale with five response categories ranging from "strongly agree, agree, undecided or don't know, disagree, and strongly disagree." This scale has been used for the attitude ana behavior items above 
except for the item requesting the respondent to write the name of the job he wants to do.

Self-report data were collected on the juveniles' social characteristics (e.g., family income, father's occupation and education, juvenile's age, and family size). These variables were used for a description of the subjects and for an examination of their contribution to the variance in del inquency.

In order to determine occupational rank as a measure of socio-economic status, it was necessary to construct a scale reflective of Saudi Arabian society. In Saudi Arabia, job prestige is more closely associated with job income than with type of job. Thus, standard occupational prestige scales used in the U.S. are inappropriate measures of occupational rank in Saudi Arabia. Having conferred with numerous colleagues, employees, and employers in saudi Arabia, I derived an approximate income range associated with all jobs listed (either as father's occupation or own desired future occupation) by the respondents in my sample. Following is the resultant scale, ranging from the highest occupational rank (level 8) to the lowest occupational rank (level 1), indicating approximate monthly income. 
Level 8

Level 7

Level 6

Level 5

Level 4

Level 3

Level 2

Level 1

Level 0
Big businessman, owner of industries

(income about 10,000 Saudi Riyal or over)

Medical doctor, pilot, engineer

(income 8,000 to 10,000 saudi Riyal)

Police Commander

(income 7,000 to 8,000 )

Middle-size businessman, bank manager, senior level government or company employee.

(income 6,000 to 7,000 Saudi Riyal)

Teacher, artist, accountant, farmer (income 5,000 to 6,000 Saudi Riyal)

Typist, truck driver, coach, translator, car mechanic, junior staff, lieutenant. (income 3,000 to 5,000 Saudi Riyal)

Taxi driver, prayer leader in a Mosque. (income 2,000 to 3,000 Saudi Riyal)

Servant or maid, janitor, tinker, small merchant, sheep herder, work messenger.

(income 1,000 to 2,000 Saudi. Riyal)

Do not work, don't know

(no income)

\section{Subjects}

As in Hirschi's study, all subjects were males. There are very few adjudicated female delinquents in Saudi Arabia, and they were not available for study. All subjects were from Riyadh, the capital city of Saudi Arabia.

Institution $A$ : The questionnaire was administered to the total population of this institution for serious delinquents $(N=150)$. Juveniles in Institution $A$ have been processed through juvenile court or are waiting for their court hearings. All juveniles were brought to the institution following arrest by the police. All have been formally 
charged with criminal acts such as using drugs, sex crimes, and theft. They are confined to the institution for a designated period of time (determined through a formal sentencing procedure). The juveniles are divided according to their crime and their age. For example, all young thieves are put in one room. There is no mixing between different offender types, so that a juvenile will not be introduced to other forms of crime. Also, there is no mixing of older and younger juveniles; all the young juveniles are on one floor of the building and all older juveniles are on a different floor. The groups share eating and recreational activities, but are under strict supervision in these settings. Also, each floor is divided into large rooms that can hold up to thirty five youths. Each room is for one kind of offender. offenders in Institution A are classified by offense type: theft, sexual crimes, alcohol, drugs and fighting.

Administering the questionnaires, I sat in each room until all respondents had completed their forms. Each session took from one to four hours depending on the size of the respondent group and the extent of administrative aid needed by particular juveniles in the group. In a few cases where youths could not read at all, it was necessary for me to read the questions and the answers and have the respondent indicate to me his response choice.

Institution B: The questionnaire was administered to the total population of this institution for status offenders $(N=96)$. (The questionnaire of one juvenile, who 
expressed an inability to understand or respond to the questionnaire, was excluded.) Juveniles in Institution B have been informally accused of "bad acts" (e.g., running away from home, smoking, leaving school, and going out with older peoplel. All were brought to the institution by parents or relatives. Release occurs upon agreement among social workers in the institution and parents or other relatives that the juvenile is ready to go home.

The population of the institution is divided into two groups according to their ages, so that again older juveniles do not mix much with the younger juveniles. I administered a questionnaire to each of the two groups separately. It took me about five hours for each group.

High School: The public high school from which a sample was drawn is located in a middle class area in Riyadh, the capital city. In high school all students take the same classes, and students are randomly assigned to particular classes at a particular time. Because the administrators felt that time could be spared in Arabic reading classes, the questionnaires were administered to students during these classes. Five of the twelve reading classes were randomly selected and included in the sample $(\mathrm{N}=129)$. Junior High School: The public junior high school is located in Riyadh also. In junior high school all students take the same classes. Students are randomly assigned to particular classes at a particular times. Because the 
administrators felt that time could be spared in art classes, the questionnaires were administered to students during these classes. Three of the seven art classes were randomly selected and included in the sample $(\mathrm{N}=58)$.

\section{Data Analysis}

The data from this study were subjected to several different types of analysis. Frequency aistributions were used to describe the sample and make comparisons between the sub-groups. A factor analysis of the bond items allowed for the identification of variable clusters as well as an examination of Hirschi's concept of social bond. Factor analyses were also done on the social background items and on the delinquency items. Finally, correlational analyses using multiple regression procedures provided for a more comprehensive assessment of relationships among the independent and dependent variables. 
CHAPTER III

DELINQUENCY IN SAUDI ARABIA: FINDINGS AND ANALYSES

\section{Frequency Distributions}

The first step in the analysis of the questionnaire data, the calculation of frequency aistributions, provided for an overview of the sample as a whole and also allowed for gross comparisons between (a) the non-institutionalized and institutionalized groups and (b) the high school students, the junior high school students, the serious offenders in Institution $A$ and the status offenders in Institution $B$. The findings are reported below.

\section{AGE}

As indicated in Table $I$, the high school students were slightly older than the other three sub-groups. The lowest mean age was for the status offenders.

\section{TABLE I}

Distribution of Age, By Sub-Groups

$\begin{array}{llll} & \text { Mean } & \text { Mode } & \text { Range } \\ \text { High School } & 17.295 & 17 & 14 \text { to } 23 \\ \text { Junior High School } & 15.621 & 16 & 12 \text { to } 19 \\ \text { Institution A } & 16.148 & 17 & 9 \text { to } 19 \\ \text { Institution B } & 14.865 & 17 & 10 \text { to } 19\end{array}$




\section{SELF-REPORT DEIINQUENCY}

In adation to the measure of official delinquency (institutionalization for serious or status offenses), delinquency was measured by responses to a series of selfreport items. The results of the self-report measure are presented in Table II.

TABLE II

PERCENTAGE OF SUB-GROUPS REPORTING HIGH INVOLVEMENT * IN DELINQUENCY, BY OFFENSE

STATUS OFFENSES

$\begin{array}{llcc}\text { High } & \text { Ir. High } & \text { Inst. } & \text { Inst. } \\ \text { School } & \text { School } & \text { A } & B\end{array}$

Defied parents

10

14

17

11

Out late at night

15

7

38

30

Burning rubber

11

19

42

18

PROPERTY OFFENSES

Minor theft

5

2

23

7

Major theft

6

2

24

5

Theft-auto part

3

3

13

7

Theft auto

2

3

15

6

Vandalism

9

2

18

18

\section{VIOLENCE}
Taken part in fight
Hurt someone badly
Used knife or club

10

7

28

38

11

3

17

19

on another

0

13

*high involvement includes responses of often (3) and sometimes (2). 
It is clear from these data that delinquency is not limited to those juveniles who have been officially recognized as offenders. However, the proportion of juveniles reporting delinguent involvement is clearly higher among the institutionalized than the non-institutionalized group. Major findings include the following:

1. Taking the sample as a whole, the most common offenses were staying out late (25\%) and "burning rubber" (24\%). The least common were the more serious offenses-assault with a knife or club (7\%) and major theit (7\%).

2. Juveniles in Institution $A$ were much more heavilyinvolved than any of the other three sub-groups in all status and property offenses (with the exception of vandalism, reported with equal Erequency by serious and status offenders). However, a higher percentage of status than serious offenders reportea involvement in weaponless crimes of violence. In fact, the most common offense for status offenders was taking part in a fight (38\%).

3. With the exception of vandalism among status offenders, high involvement in property offenses was extremely uncommon among the high schoolers, junior high schoolers and status offenders. Junior high school students reported particularly low involvement, with not more than 3\% reporting high involvement in any of the property offenses. 4. Within each sub-group, "burning rubber" appears to be a relatively common offense, with close to one half of serious offenders reporting high involvement in this behavior. 
5. The rost frequently-reported offense category for junior high school stuäents was status offenses. For high school students, status offenses and weaponless crimes of violence were the most frequently-reported offense categories.

\section{SOCIAL BACKGROUND CHARACTERISTICS}

The data on social background characteristics clearly incicated a social class bias in favor of the school sample (see Table II for data).

\section{TABLE III}

SOCIAL BACKGROUND CHARACTERISTICS OF SUS-GROUPS, PERCENT AGREEING*

LIVING ARTANGEMENTS

$\begin{array}{llcc}\text { High } & \text { Jr High } & \text { Inst. } & \text { Inst. } \\ \text { School } & \text { School } & \text { A } & \text { B }\end{array}$

Have own room

Live in modern villa

Own home

Father not living
45

83

85

7
33

53

81

10
48

53

79

13

FAMILY INCOME/JOB/EDUCATION

Fainily monthly income 3,000+ Sauaji Riyal

Father works full time

Father's joj level $4+$

Family has/ajoes receive welfare

Father's education

nigh school;
71

71

26

10

21

10

69

29
62

54

65

63

23

22

21


The institutionalized group was more likely than the school group to be disadvantaged on all measures of socioeconomic status. However, this difference was accounted for primarily by the relative advantage of the high school students and the relative disadvantage of the status offenders. With the exception of "family receives welfare" laffirmed much more frequently by both serious and status offenders than by either high school or junior high school students), serious offenders and junior high school students had similar socio-economic profiles. These two latter subgroups were more likely than the high school students and less likely than the status offenders to be socio-economically disadvantaged. Major findings on individual items included the following:

1. The proportion of respondents who reported that they lived in a modern villa ranged from a high of $83 \%$ (high school students) to a low of $39 \%$ (status offenders). slightly more than half of the junior high school students and of serious offenders reported living in a modern villa.

2. "Father not living" was reported most frequently among status offenders and least frequently among high school students. The relatively high rate of deceased fathers among the status offenders may be a finding of some significance in that Saudi Arabian society attaches a great deal of importance to the father's role as guardian of and moral guide to his sons. Status offenders, it should be recalled, were brought to Institution $B$ in most cases 
because the family felt that they could not control their child's behavior.

3. Overall, approximately $2 / 3$ of the respondents reported having a family income of $3,000+$ Saudi Riyal and having a father who worked full-time. Although the frequency differences were not large, the school group was more likely than the institutionalized group to have a high family income and a full-time working father. The trend identified in the data on living arrangements, i.e., the most favorable socio-economic conditions for high school students and the least favorable for status offenders, was also reflected in the data on family income and full-time working fathers.

4. A minority of the respondents in each of the subgroups reported that their fathers had high-level jobs (level four or above on the occupational ranking scale). Differences between institutionalized offenders and the school students were minimal.

5. "Receiving welfare" was reported most frequently among institutionalized juveniles. Both serious and status offenders had relatively high rates of welfare recipiency $(41 \%$ each). In contrast, high school students were highly unlikely to be members of welfare families.

6. While a minority of the respondents reported that their fathers had a high school or beyond high school education, the high school students were much more likely than the other sub-groups to have fathers who had completed or gone beyond high school. 


\section{HIGH BOND BY SCHOOL-RELATED ITEMS}

With the exception of items measuring school achievement and future school plans, the majority of respondents in all sub-groups responded positively on school-related items (see Table IV for data on school-related items). Eighty five percent or more of the juveniles in all sub-groups reported that they were satisfied with school, that school helped them to be mature, and that they studied in order to be well-educated. Of the sub-groups, junior high school students were the most positive on items measuring school attachment, and high school students were the most positive on items measuring school commitment. The data consistently showed serious offenders to have the weakest bond with school.

School attachment (satisfied with school, school helps me be mature, study to be educated, school boring, school waste of time, teachers interested in my work).

The great majority agreed that they were satisfied with school, that school helped them to be mature, and that they studied to be well-educated. However, the lowest rate of agreement on all three items was found among the serious offenders.

The great majority of high school and junior high school students disagreed with the statements that school was boring and that school was a waste of time. The institutionalized juveniles were much more likely than the school 
students to agree with these statements. On both items, serious offenders had the highest rate of agreement.

\section{TABLE IV}

PERCENTAGE OF SUB-GROUPS REPORTING HIGH BOND, BY SCHOOL-RELATED ITEMS

SCHOOL-RELATED ITEMS

$\begin{array}{lccc}\text { High } & \text { Jr. High } & \text { Inst } & \text { Inst } \\ \text { School } & \text { School } & \mathrm{A} & \mathrm{B}\end{array}$

\begin{tabular}{|c|c|c|c|}
\hline School boring (D) * & 84 & 93 & 61 \\
\hline $\begin{array}{l}\text { Satisfied with } \\
\text { school }(A)^{* *}\end{array}$ & 95 & 95 & 85 \\
\hline $\begin{array}{l}\text { School helps me } \\
\text { be mature (A) }\end{array}$ & 96 & 100 & 91 \\
\hline School ability (A) & 33 & 40 & 40 \\
\hline Do best work (A) & 52 & 69 & 62 \\
\hline $\begin{array}{l}\text { School waste of } \\
\text { time (D) }\end{array}$ & 85 & 88 & 51 \\
\hline $\begin{array}{l}\text { Study to be } \\
\text { educated (A) }\end{array}$ & 95 & 98 & 87 \\
\hline $\begin{array}{l}\text { Teachers interested } \\
\text { in my work (A) }\end{array}$ & 70 & 91 & 85 \\
\hline $\begin{array}{l}\text { Complete high } \\
\text { school (A) }\end{array}$ & 95 & 75 & 63 \\
\hline Attend college (A) & 90 & 63 & 57 \\
\hline $\begin{array}{l}\text { Graduate from } \\
\text { college (A) }\end{array}$ & 87 & 61 & 33 \\
\hline $\begin{array}{l}\text { Interested in } \\
\text { more reading }(A)\end{array}$ & 71 & 73 & 61 \\
\hline Get good grades (A) & 47 & 45 & 40 \\
\hline
\end{tabular}


The great majority of junior high school students, serious offenders and status offenders felt that teachers were interested in their work. A somewhat lower rate of high school students (but still a majority of $70 \%$ ) agreed with this statement.

School Commitment (complete high school, attend college, graduate from college).

High school students were highly likely and much more likely than any of the other sub-groups to say that they planned to complete high school, that they expected to attend college, and that they had made plans to attend and graduate from college. A notably low percentage (33\%) of the serious offenders indicated that they had made plans to attend and graduate from college.

School achievement (school ability, do best work, good grades).

Asked to rate themselves on school ability in comparison to others in their grades, the great majority of the respondents rated themselves as average or lower. Surprisingly, high school students, who indicated the highest commitment to future schooling, rated themselves relatively low on school ability.

High school students were also the least likely of all sub-groups to say that they came close or very close to doing the best work they were able to do in school. Status offenders were the most likely to rate themselves favorably on their school efforts. 
Less than half of the respondents in all sub-groups reported that they got very good or excellent grades in school. Differences between the sub-groups were minimal.

\section{HIGH BOND BY FRIEND-RELATED ITEMS}

From the control perspective, attachment to friends is an indicator of social bond. Findings from some studies, however, suggest that adolescents are strongly influenced by their friends and that if juveniles are attached to delinquent peers, they are likely to be delinquent themselves. (See Gibbons, 1981). Thus, whether or not attachnent to friends operates as a control against delinquency may depend on the behaviors of the friends. Involvement of friends in delinquency was not measured in this study; however, the respondents were asked about their attachment to friends (see Table V).

\section{TABLE V}

PERCENTAGE OF SUB-GROUPS REPORTING HIGH BOND, BY FRIEND-RELATED ITEMS

$\begin{array}{lcccc}\text { FRIEND-RELATED ITEMS } & \begin{array}{l}\text { High } \\ \text { School }\end{array} & \begin{array}{l}\text { Jr High } \\ \text { School }\end{array} & \begin{array}{c}\text { Inst } \\ \text { A }\end{array} & \begin{array}{c}\text { Inst } \\ \text { B }\end{array} \\ \text { Friends important (A)* } & 82 & 85 & 66 & 74 \\ \text { Time with friend (A) } & 66 & 47 & 50 & 64 \\ \text { Help friend, even } & & & & \\ \text { stretch truth (A) } & 25 & 25 & 39 & 23 \\ \text { Have friends (A) } & 99 & 95 & 97 & 97 \\ \text { * A strongly agree or agree } & & & \end{array}$


overall, the great majority of respondents in all subgroups reported that they had friends. Friends seemed to be considerably more important in the lives of school students than of institutionalized delinquents. The great majority of school students felt that friends were important in their lives; friends were least likely to be important to serious offenders.

High school students were the most likely to agree that it was important to them to spend time with their friends; however, the rate of status offenders agreeing with this item was only slightly lower $(64 \%$ compared to $66 \%$ of high school students). Only about $1 / 2$ of the junior high school students and serious offenders indicated that spending time with friends was important to them.

Approximately $1 / 4$ of the high school, junior high school and status offender groups agreed that they would help a friend even if it meant stretching the truth to do so. A significantly higher proportion (39\%) of the serious offenders agreed with this item.

\section{HIGH BOND BY RELIGION-RELATED ITEMS}

Religion is highly-valued in Saudi Arabian society, and the responses of the juveniles to the religion items reflected a recognition and acceptance of this value (See Table VI). The overwhelming majority of respondents in all sub-groups indicated that their parents would respond negatively if they (their children) did not pray. 
TABLE VI

PERCENTAGE OF SUB-GROUPS REPORTING HIGH BOND, BY RELIGION-RELATED ITEMS

$\begin{array}{ccccc}\text { RELIGION-RELATED ITEMS } & \begin{array}{l}\text { High } \\ \text { School }\end{array} & \begin{array}{c}\text { Jr High } \\ \text { School }\end{array} & \begin{array}{c}\text { Inst } \\ \text { A }\end{array} & \begin{array}{c}\text { Inst } \\ \text { B }\end{array} \\ \text { Pray at mosque (A)* } & 95 & 97 & 78 & 90 \\ \begin{array}{l}\text { Parents reaction } \\ \text { if doesn't pray (-) }\end{array} & 88 & 93 & 89 & 88 \\ \text { All friends pray (A) } & 87 & 91 & 59 & 57 \\ \text { * A = strongly agree or agree } & & & \end{array}$

The most significant difference between the school students and the official delinquents was found in their responses to whether or not all their friends prayed (the one measure in the study of friends' behavior). While almost $90 \%$ of the school students said that all their friends prayed, less than $60 \%$ of the institutionalized offenders gave affirmative responses to this question. Additionally, while almost all of the school students said that they themselves always prayed at the mosque, only about $3 / 4$ of the serious offenders reported regular involvement in prayer activity. Status offenders showed only slightly less involvement than the school students in prayer activity. On all measures, junior high school students showed the highest religious bond of all sub-groups. 
HIGH BOND BY JOB-RELATED ITEMS

The great majority of respondents intended to get a job, had decided on their future job, and believed that their future job plans would work out. However, the serious offenders were slightly less likely than the other sub-groups to intend to get a job and to think that their future job plans would work out (see Table VII for data on job-related items).

\section{TABLE VII}

PERCENTAGE OF SUB-GROUPS REPORTING HIGH BOND, BY JOB-RELATED ITEMS

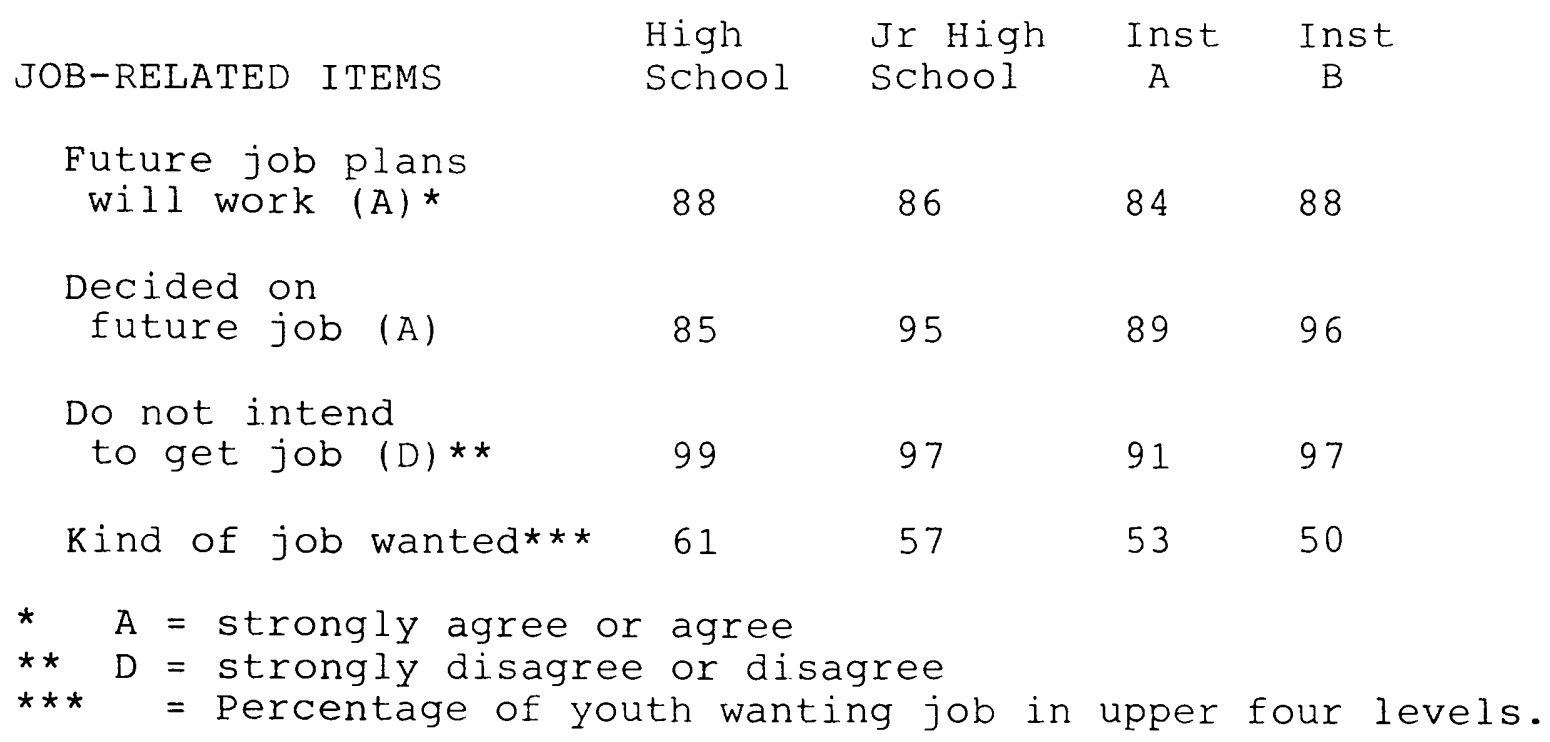

As described earlier (see Chap. 2), jobs were ranked on the basis of income and prestige from a high of eight to a low of one. Overall, slightly more than half of the respondents reported wanting jobs in one of the upper four levels. Those most likely to want jobs in one of the four upper levels 
were high school students followed in order by junior high school students, serious offenders and lastly status offenders.

\section{HIGH BOND BY FANILY ATTACHMENT}

Only small differences existed between the sub-groups on the items measuring closeness to parents (see Table VIII for data on family attachment). The great majority of respondents in all sub-groups agreed that they were close to their mother. Somewhat fewer (about 3/4) of the respondents in each sub-group agreed that they were close to their father. When the juveniles were asked about their desire to be like their father, significant group differences appeared. Serious offenders were the most likely to indicate that they would like to be like their fathers when they became adults. In fact, the institutionalized offenders were much more likely than the school students to aspire to be like their fathers.

TABLE VIII

PERCENTAGE OF SUB-GROUPS REPORTING HIGH BOND, BY FAMILY ATTACHMENT

\begin{tabular}{|c|c|c|c|}
\hline FAMILY-RELATED ITEMS & $\begin{array}{l}\text { High } \\
\text { School }\end{array}$ & $\begin{array}{l}\text { Jr High } \\
\text { School }\end{array}$ & $\begin{array}{c}\text { Inst } \\
\mathrm{A}\end{array}$ \\
\hline Close to father (A)* & 78 & 76 & 78 \\
\hline Close to mother (A) & 91 & 90 & 88 \\
\hline $\begin{array}{l}\text { Want to be like } \\
\text { father (A) }\end{array}$ & 62 & 67 & 83 \\
\hline
\end{tabular}


HIGH BOND BY MISCELLANEOUS ITEMS

(See Table IX)

Belief (feel guilty, conscience punishes me, bad to cheat).

The above items were included to measure the element of social bond referred to by Hirschi as belief. The majority of respondents agreed with the statement "I do things I feel guilty about afterwards." However, over $80 \%$ of the serious offenders (compared to approximately $2 / 3$ of each of the other sub-groups) responded affirmatively to this statement. In other words, those juveniles who had been officially designated as serious law-violators were much more likely than those not so-designated to feel guilty about their behaviors.

TABLE IX

PERCENTAGES OF SUB-GROUPS REPORTING HIGH BOND BY MISCELLANEOUS ITEMS

\begin{tabular}{|c|c|c|c|}
\hline MISCELLANEOUS ITEMS & $\begin{array}{l}\text { High } \\
\text { School }\end{array}$ & $\begin{array}{l}\text { Jr High } \\
\text { School }\end{array}$ & $\begin{array}{l}\text { Inst } \\
\mathrm{A}\end{array}$ \\
\hline Feel guilty $(A)$ * & 65 & 68 & 81 \\
\hline $\begin{array}{l}\text { Conscience } \\
\text { punishes me (A) }\end{array}$ & 95 & 84 & 85 \\
\hline Bad to cheat (A) & 76 & 32 & 51 \\
\hline $\begin{array}{l}\text { Spend evenings } \\
\text { for fun }(D) * *\end{array}$ & 59 & 72 & 43 \\
\hline $\begin{array}{l}\text { Neighborhood care } \\
\text { for other (A) }\end{array}$ & 64 & 77 & 77 \\
\hline $\begin{array}{l}\text { Feel nothing } \\
\text { to do (D) }\end{array}$ & 29 & 32 & 22 \\
\hline $\begin{array}{l}\text { * }=\text { strongly agree or } \\
\star \star \quad D=\text { strongly disagree }\end{array}$ & $\begin{array}{l}\text { agree } \\
\text { or diso }\end{array}$ & ree & \\
\hline
\end{tabular}


High school students, reflecting an internal control on their behaviors, were extremely likely (95\%) and much more likely than any of the other sub-groups to agree with the statement "When I do wrong, my conscience bothers me." High school students were even more likely than the other subgroups to agree that it was bad to cheat. While half of the serious offenders agreed with this latter statement, only $1 / 3$ of the junior high students and status offenders thought that it was bad to cheat.

Involvement (spend evenings for fun).

According to the control perspective, spending evenings out with friends is a measure of negative involvement and thus weak social bond. The institutionalized juveniles were much more likely than the school students to report that they usually spent their evenings with friends for fun and recreation. Junior high school student were the least likely and the serious offenders the most likely to agree that their evenings were typically spent in this way.

Attachment (neighborhood care for other).

Reflecting a relatively low attachment to their neighborhood, slightly fewer than $2 / 3$ of the high school students agreed that people in their neighborhood knew and cared for each other. In comparison, approximately $3 / 4$ of each of the other sub-groups agreed with this characterization of their neighborhood. 
The analysis of the frequency distributions revealed both similarities and differences amony the sub-groups in the responses to the indiviaual items assumed to measure the strength of social bond. The analysis to tis point, however, proviaes no information about the conceptual nature of the social bond itself. In order to examine Hirschi's contention that the bond consists of four elements with specific variables as inaicators of each of those elements, a factor analysis of the data from the present stuay was undertaken. The results of this analysis are described in the following section.

An Examination of the Social Bond Concept Through Factor Analysis

According to Babie, "Factor analysis is a complex algebraic method for determining the general aimensions or factors that exist within a set of concrete observations" (1973:535). Factor analysis was done in this study to identify variable clusters as well as to determine whether or not the factors would conform to Hirschi's model. That is, do the data indicate that attachment, belief, commitment and involvement are identifiable and unique aimensions of social bond?

In a similar endeavor, wiatrowski, et al. used a varimax factor rotation which resulted in seven rather than four factors. In addition to the larger number, the factors which emerged were not entirely compatible with Hirschi's 
theoretical model, leading the authors to conclude that their "results suggest a more complex interpretation of the social bond than that presented by Hirschi" (Wiatrowski, et $\underline{\text { al }} ., 1981)$.

In the present study, an initial analysis was made of a factor matrix using principal factors with iterations. Generally, the originally factors as extracted contained variable clusters with an institutional emphasis. For example, variables which loaded highly on Factor I were all schoolrelated items. Factor II contained family-related items; Factor III emphasized friend-related items, and Factor IV was a job-related factor. This factor structure, then, contradicts Hirschi's argument that indicators of bond elements cross institutional areas. Rather, on the basis of the analysis of this factor structure, it might be argued that the basic elements of social bond are institutional or substantive, and that within each institutional area are the more abstract dimensions of attachment, belief, commitment and involvement.

A more refined factor structure was sought by obtaining a varimax rotated factor matrix. Through this process, ten factors were identified. The factors, described below, do conform more closely to Hirschi's bond model. However, the elements are not uniquely contained in all instances, and the institutional emphasis is retained (see Table $\mathrm{X}$ ). 


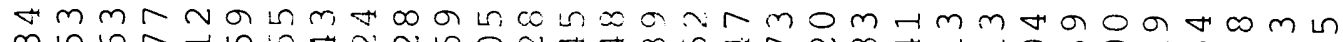
$m$ m

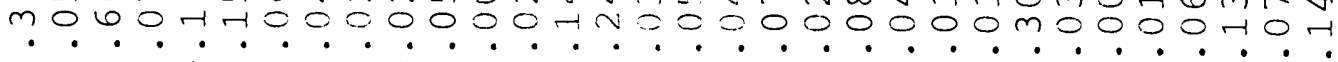

1

11

का

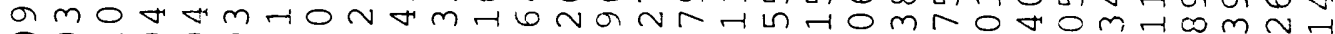

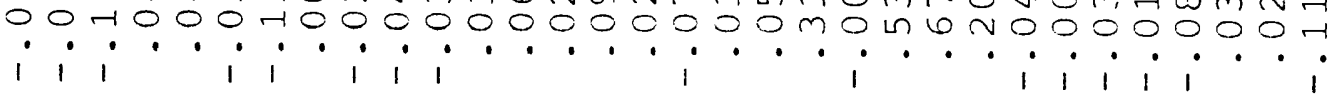

i

$\stackrel{\mapsto}{\mapsto}$

w nNOH-m

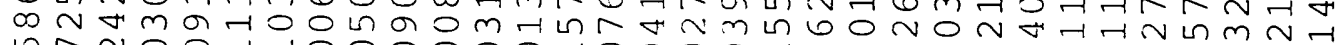

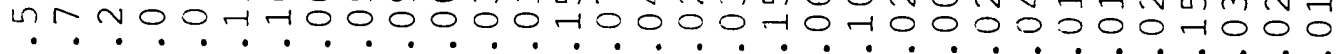

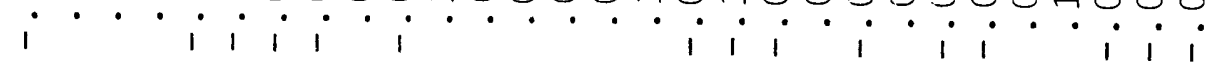

๒

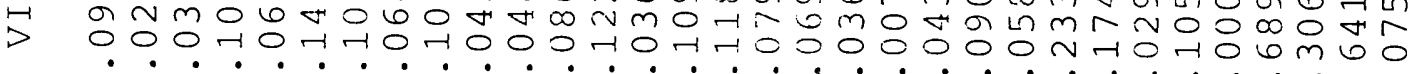
1
11

w

$\mapsto \quad 6$ a $000 \omega r 00-100000000070000400000000$ i.

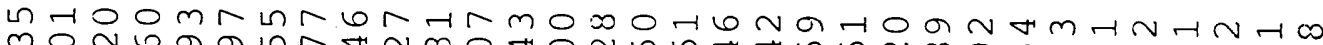
mon 0 a -

$$
\text { I }
$$

nom

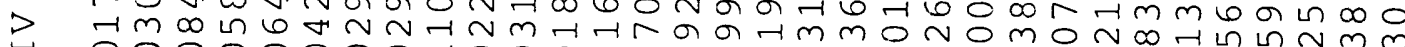

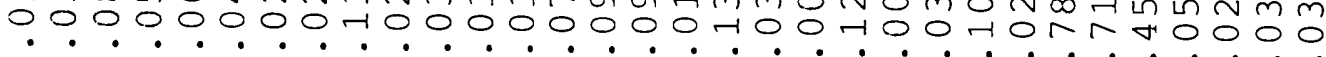

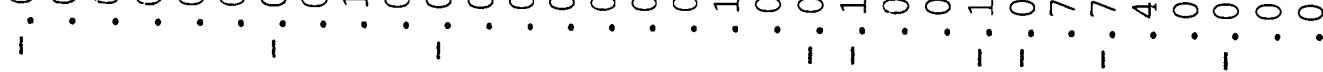

H

H बनुO

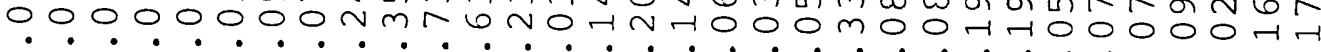

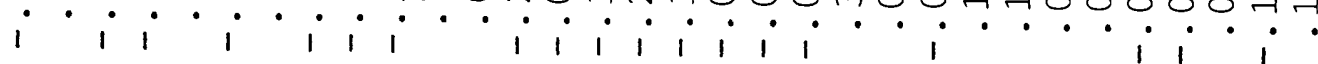

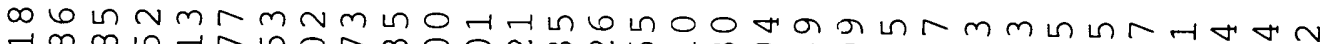
H न

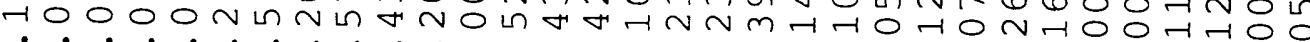
i i i i i $1 i$

Gr

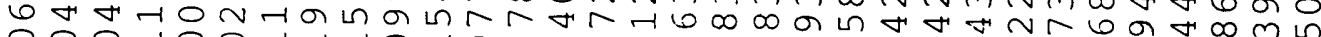

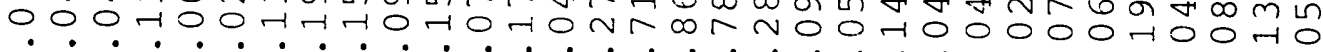

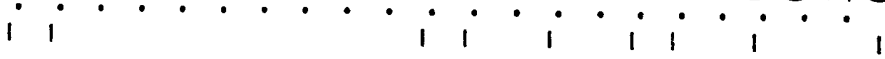


Factor I

This factor clearly reflects commitment to school. The three variables with substantial loadings were plan to complete high school (V20), plan to attend college (V21), and plan to graduate from college (V22).

Factor I I

Factor II also emphasizes school-related items but is multi-dimensional from Hirschi's bond perspective. The factor seems to suggest a new dimension, which might be labeled achievement orientation. Items with high loadings included working hard in school (V11), satisfied with school (V13), school helps me be mature (V14), study to be educated (V17), teachers interested in school work (V18), do best school work (V11), future job plans will work (V19), and interested in doing more school work (V23).

\section{Factor III}

The two items which loaded highly on this factor were school is boring (V15) and school is a waste of time (V16). These negative school attitudes are indicators of school attachment.

\section{Factor IV}

Factor IV focuses on job commitment, with high loadings on decided on particular job (V53) and intend to get a job (V54). However, these items do not reflect aspirations to achieve any particular kind or level of job and thus differ 
somewhat from Hirschi's implication that commitment involves upward status aspirations.

Factor V

This is a school achievement factor with high loadings on school ability (V10), get gooà grades (V12), and, to a lesser extent, do best work (V11). Hirschi suggested that self-report school achievement was an indicator of school attachment.

\section{Factor VI}

Emphasizing attachment to friends, Factor VI had high loadings on friends important (V8) and time with friends important (V9).

Factor VII

Religion was the institutional or substantive area to which Factor VII pertained. The highest loadings were respectively on pray at the mosque (V58), friends pray (V60), and parents reaction to not praying (V59). It could be argued that these items represent either or both involvement and belief.

Factor VIII

This factor shows attachment to parents. The two items with high loadings were close to father (V5) and close to mother (V6). 
Factor IX

Factor IX clearly reflects Hirschi's concept of belief, with high loadings on conscience punishes me for wrongdoing (V27), feel guilty when do something wrong (V26), and bad to cheat (V25).

Factor $\mathrm{X}$

The variable with the highest loading on Factor $\mathrm{x}$ was want to be like father (V7). Close to father (V5) and neighborhood cares for each other (V29) also had relatively high loadings. Thus, this variable appears to emphasize attachment.

Findings from the factor analysis of the Saudi Arabian data, then, support the conclusion of wiatrowski, et al. that the concept of social bond may be more complicated than Hirschi envisioned. The present analysis does not support the view that attachment, belief, commitment, and involvement are unique elements which cross substantive or institutional areas.

In addition to providing useful theoretical information about social bond, the factor analysis was utilized in selecting items for the construction of new variables (thus reducing the number of items to be used in the multiple correlational analyses). For example, a new variable (school plans) was created by combining complete high school, attend college, and attend and graduate from college. For a 
list of the new variables derived from this factor analysis, see Appendix C.

Factor Analyses of Self-report Delinquency and social Background Items

In addition to the bond items, factor analyses were also done separately on the delinquency items and on the social background items. Only two factors emerged from the analysis of the delinquency items--the first emphasizing property offenses, and the second emphasizing crimes of violence. From the analysis of the delinquency items, an overall scale score was derived and transformea into a new variable labeled DLNQSUM. This variable was subsequently used as the measure of self-report delinquency in the multiple correlation analyses.

\section{Correlational Analyses}

An effort was made through correlational analyses utilizing multiple regression procedures to identify the best predictors of self-report delinquency (DLQNSUM) and official delinquency (INCARCERATION). Stepwise regressions identified those variables which explained the greatest portion of the variance in both unofficial and official delinquency. Findings from the correlation analyses are presented in the following pages. 


\section{CORRELATIONS WITH DLNQSUM, BY GROUPS} (See Table XI)

\section{Group I: Junior high school students.}

For junior high school students, self-report delinquency correlatea most highly with number of people living at home $(.540)$. Thus, the single best predictor of delinquency among junior high school students had to do with living arrangements rather than social bond. On the other hand, the three variables with the next highest correlations (all negative) were school bond items (i.e., school work, school plans, and school ability). These findings suggest that delinquency for this group was controlled by commitment to future schooling and by the achievement orientation discussed earlier. Pray, a factor-derivea variable combining self prays and friends pray, showed the next highest correlation with self-report delinquency.

Another commitment variable, aspiring to a high level job, also appeared to work as a control against delinquent involvement. Contrary to assumptions that delinquency is associated with low social class status, living in a modern villa (a measure of high social class) was positively correlated with delinquency among junior high school students. Overall, the variables entered into the multiple regression equation explained 53\% of the variance (the highest proportion of variance explained for any of the groups). Three variables--number of people living at home, live in a 
TABIE XI

CORRELATIONS WITH DLNQSUM, BY GROUPS

\section{Junior High \\ Group I}

\begin{abstract}
V4 Monthly income
\end{abstract}
0.084

0.540 *

$-0.124$

V37 Live in a

modern villa

V56 Family re-

ceives welfare

V57 Father's

Education

FV1** School Plan

$-0.176$

$-0.055$

$-0.091$

FV2 School Work

$-0.405 *$

$-0.424$

FV3 School Interest -0.210

FV4 School Ability -0.310

FV5 Pray at Mosque -0.306

FV7 Fathid

V55 Kind of Job

$-0.172$

$-0.239$

FV8 Friends

$$
\begin{aligned}
& 0.063 \\
& \frac{R .7251}{2} \\
& R^{2} .5258
\end{aligned}
$$

STEPWISE

R. 6510

2

R. .4238
0.148 *

$-0.086$

0.031

0.060

$-0.054$

$-0.049$

0.029

High School

Status

Serious

Group IV

0.106

0.195 *

$-0.031$

0.148

0.154

$-0.238$

0.064

$-0.070$

$-0.238$

-0.417 *

$-0.264$

$-0.306$

$-0.418^{*}$

$-0.299$

$-0.088$

0.020

$\mathrm{R} .5877$

2

R . 3454

STEPWISE

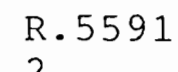

2

R . 3126
$-0.188$

$-0.165$

$-0.098$

$-0.228$

$-0.247 *$

$-0.105$

-0.163 *

$-0.164$

$\overline{\mathrm{R} .5207}$

2

R . 2711

STEPWISE

R. 4274

2

R .1827
$-0.193$

$-0.160$

$-0.202 *$

$-0.051$

$-0.402 *$

$-0.081$

$-0.029$

0.217 *

$\overline{\mathrm{R} .5271}$

2

R . 2778

STEPWISE

R. 5066 2

R. .2567

* variables entered in stepwise multiple equation

* FV refers to new variables derived from the factor analysis 
modern villa, and school plans--accounted for $42 \%$ of the variance.

\section{Group II: High school students.}

The best predictors of self-report delinquency among the high school students suggested a weak religious bond (FV5, pray) and a weak achievement orientation (FV2, school work). Correlations between these two variables and delinquency involvement were -.418 and -.417 respectively. Perceptions of school ability showed the third highest (negative) correlation with delinquency. Also showing relatively high (negative) correlations were (in order of the size of the correlation) father identification, school interest, and school plans. In terms of the individual correlations, then, bond items were better predictors than social background items of delinquency involvement in high school students.

Taken together, the fourteen variables presented in Table XI explained 35\% of the variance. Three variables (number living at home, school work, and pray) explained $31 \%$ of the variance.

\section{Group III: Status offenders.}

The fourteen variables entered into the multiple regression equation were considerably less capable of predicting the self-report delinquency of status offenders than of the school groups. Additionally, the highest correlations of individual items with DLNQSUM for status offenders were 
considerably lower than the highest correlations for the school groups.

As for high school students, the measure of weak religious bond was the best predictor of delinquency involvement among status offenders. With a correlation of.237, monthly family income (a poor predictor of delinquency among the school groups) was the second best predictor of status offender delinquency. However, contrary to what might be expected, monthly income showed a positive relationship to delinquent involvement for the status offenders. Perception of school ability was the only other variable to show a (negative) correlation of more than .20 .

of some theoretical interest was the moderately high (-.164) correlation between friends and delinquency. Contrary to Hirschi's agruments, low attachment to friends seemed to work as a control against delinquency among status offenders.

In the stepwise equation, three variables--monthly family income, kind of job wanted, and pray--explained $18 \%$ of the variance. In this latter analysis, then, coming from a family with a high income, having low job aspirations, and having a weak religious bond were associated with delinquency among status offenders.

\section{Group IV: Serious offenders.}

A substantial negative correlation (-.402) was found between pray and the self-report delinquency of juveniles 
who had been incarcerated for serious delinquency. It should be recalled that the factor-derived variable "pray" combined two items--pray everyday at the mosque and friends pray everyday at the mosque. One conclusion that might be drawn from this finding is that having friends with a weak (religious) bond is associated with a higher level of both unofficial and official delinquency. Additionally, serious offenders were the only group for which attachment to friends (friends are important/time with friends is important, FV8) showed a strong positive correlation with delinquency involvement. Negative school attitudes (school boring/school waste of time, FV3) was the only other variable with a correlation of more than .20 .

Like the delinquency of status offenders, the delinquency of serious offenders was not explained as well by the independent variables as it was for the school groups. Four variables--number people living at home, school interest, pray, and friends--explained $26 \%$ of the overall $28 \%$ of explained variance. Thus, having a large number of people living at your home, negative school attitudes, a weak religious bond but positive attachment to peer's (who also have a weak religious bond) explained a fair amount of the self-report delinquency of juveniles incarcerated for serious offenders. 


\section{Summary}

For all groups, a strong religious bond appeared to be a relatively effective control against delinquency. A strong achievement orientation was a highly effective control against the delinquency of junior high school and high school students, while only moderately effective as a control against delinquency among incarcerated offenders.

For junior high school students, living arrangements (particularly living in a home with many people, and to a lesser extent not having a room of your own) predictea delinquency. For both junior high and high school students, strong school bond (as indicated by the high correlations on all school-related items) was an effective control against del inquency.

The independent variables in this regression analysis explained much less of the delinquency of incarcerated offenders than that of the school students. However, $26 \%$ of the variance in the delinquency of serious offenders was explained by negative school attitudes, weak religious bond, and strong attachment to friends. 
CORRELATIONS BETWEEN SOCIAL BOND ITEMS, INCARCERATION AND DLNQSUM

The correlations presented in Table XII provide information on the relationships of factor-derived bond items to INCARCERATION and DLNQSUM. These bond i.tems explained more of the variance in both official and unofficial delinquency than did the social background items (see Table XIII).

The single best predictor of INCARCERATION was

school attitudes (SCH INT). Additionally, school plans and pray showed high negative correlations with INCARCERATION. The only other item with a relatively high correlation with INCARCERATION was father identification, but here the relationship was not in the predicted direction. That is, identification with father increased the likelihood of being incarcerated for delinquency. Interestingly, the relationship of father identification to self-report delinquency was in the expected negative direction. The five variables entered into the stepwise regression--school plans, school work, school interest, pray, and father identification-explained $26 \%$ of the overall $27 \%$ of explained variance in INCARCERATION.

Pray, showing the highest correlation of any item to either of the delinquency measures, was the best predictor of self-report delinquency (.42). Three school-related items--school plans, school work, and school interest--were also highly negatively correlated with DLNQSUM. School work, the variable derived from the factor emphasizing 
achievement orientation, did not predict INCARCERATION; however, as noted, school plans and school interest were effective predictors of both INCARCERATION and DLNQSUM. The four variables entereä into the stepwise equation--school plans, school interest, friends, and pray--contributed almost all of the explained variance in DLNQSUM.

These factor-derived bond variables, then, were relatively good predictors both of INCARCERATION and of DLNQSUM, explaining $27 \%$ of the variance in the former and $26 \%$ of the latter.

TABLE XII

CORRELATIONS BETWEEN SOCIAL BOND ITEMS, INCARCERATION, AND DLNQSUM

SCH PLAN
SCH WRK
SCH INT
SCH ABI
JOB WANT
KND JOB
FRIENDS
PRAY
CLOS PAR
FATHID
GUILT

$\mathrm{SCH}$ PLAN

SCH WRK

$\mathrm{SCH}$ INT

$\mathrm{SCH}$ ABI

JOB WANT

KND JOB

PRAY

CLOS PAR

GUILT
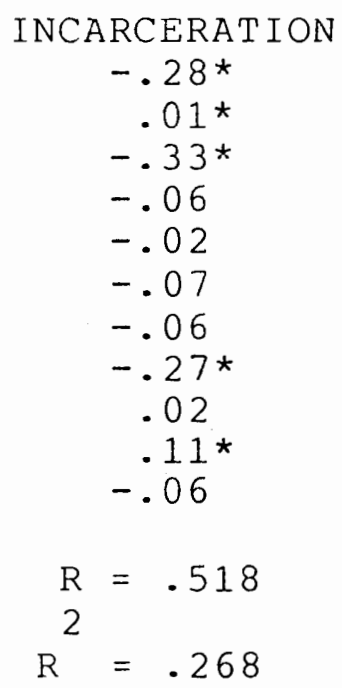

$\begin{aligned} \star \text { STEPWISE } & \mathrm{R} \\ 2 & =.511 \\ \mathrm{R}^{2} & =.261\end{aligned}$

$\begin{aligned} R & =.507 \\ 2 & R^{2}=.257\end{aligned}$

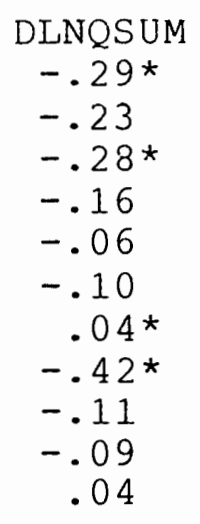

$\mathrm{R}=.510$

$\mathrm{R}=.260$ 
CORRELATIONS BETWEEN SOC BACKGROUND ITEMS, INCARCERATION AND DLNQSUM

The analysis presented in Table XII revealed several substantial correlations between socjal background items and official delinquency (INCARCERATION), but only one moderate correlation between such items and self-report delinquency (DLNQSUM). Overall, the social background items explained approximately 16\% of the variance in INCARCERATION but only 2\% of the variance in DLNQSUM. Thus, it is quite clear that socio-economic status was a much better predictor of incarceration for delinquency than of self-report involvement in delinquency.

The single best predictor of INCARCERATION was family has or does currently receive welfare (.32). Living in a modern villa also appeared to be an effective control against being incarcerated for delinquency. Neither of these variables was effective in predicting actual involvement in delinquency. Similarly, father's status (father not living and low level of father's education) was of relatively significant importance in predicting INCARCERATION but not DLNQSUM. In fact, the only item which was strongly correlated with self-report delinquency was number in home (.15). While monthly income was not a strong predictor of either INCARCERATION or DLNQSUM, it is of interest that the direction of the relationship was negative for INCARCERATION and positive for DLNQSUM. 
The findings from this analysis do suggest that coming from a welfare family, living in sub-standard housing, and having a father who is either deceased or poorly educated increases the likelihood of being incarcerated for delinquent behavior.

TABLE XIII

CORRELATIONS BETWEEN SOC BACKGROUND ITEMS, INCARCERATION AND DLNQSUM

INCARCERATION

DLNQSUM

V4 Monthly income

V30 \# In Home

V31 Have Own Room

V37 Live in Mod Villa

V42 Own Home

V45 Fa Wk Full time

V51 Fa Not Living

V52 Fa's Job Level

V56 Receive Welfare?

V57 Fa's Educ Level

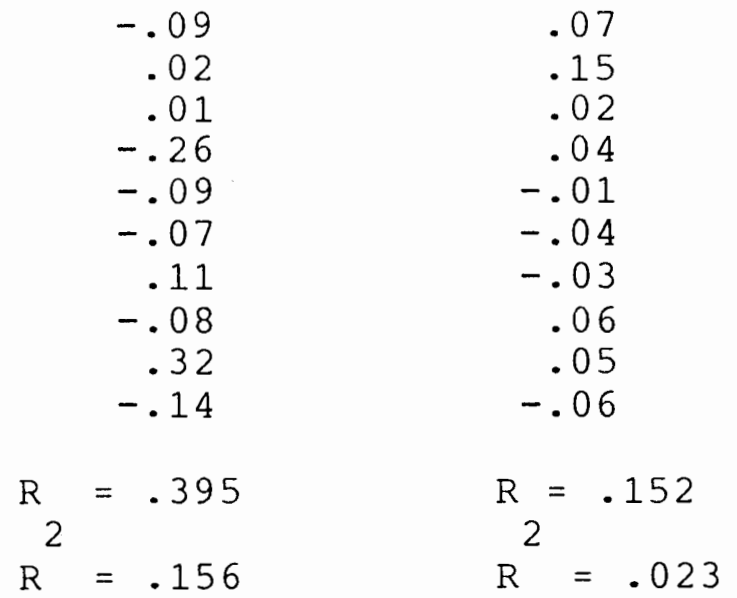

STEPWISE MULTIPLE CORRELATIONS: INDEPENDENT VARIABLES BY INCARCERATION AND DLNQSUM

In order to identify the independent variables which best explained INCARCERATION and DLNQSUM and to note the contribution of each to the variance in each of the two measures of delinquency, stepwise multiple regressions were run. The results of these analyses are presented in Table XIV. 


\section{TABLE XIV}

STEPNISE MULTIPLE CORRELATIONS: INDEPENDENT VARIABLES BY INCARCERATION AND DLNQSUM

INCARCERATION

zero

order partial

$-.232$

.216

$-.262$

$-.287$

$\begin{array}{lrr}\text { SCH WRK } & .009 & .180 \\ \text { LIVE } & & \\ \text { MOD VILLA } & -.264 & -.184 \\ \text { FATH ID } & .113 & .161\end{array}$

$\begin{array}{lrr}\text { SCH WRK } & .009 & .180 \\ \text { LIVE } & & \\ \text { MOD VILLA } & -.264 & -.184 \\ \text { FATH ID } & .113 & .161\end{array}$

$\begin{array}{lrr}\text { SCH WRK } & .009 & .180 \\ \text { LIVE } & & \\ \text { MOD VILLA } & -.264 & -.184 \\ \text { FATH ID } & .113 & .161\end{array}$

MOD VILLA -.264
FATH ID $\quad .113$
$\begin{aligned} \mathrm{R} & =.57878 \\ \mathrm{R}^{2} & =.33498\end{aligned}$

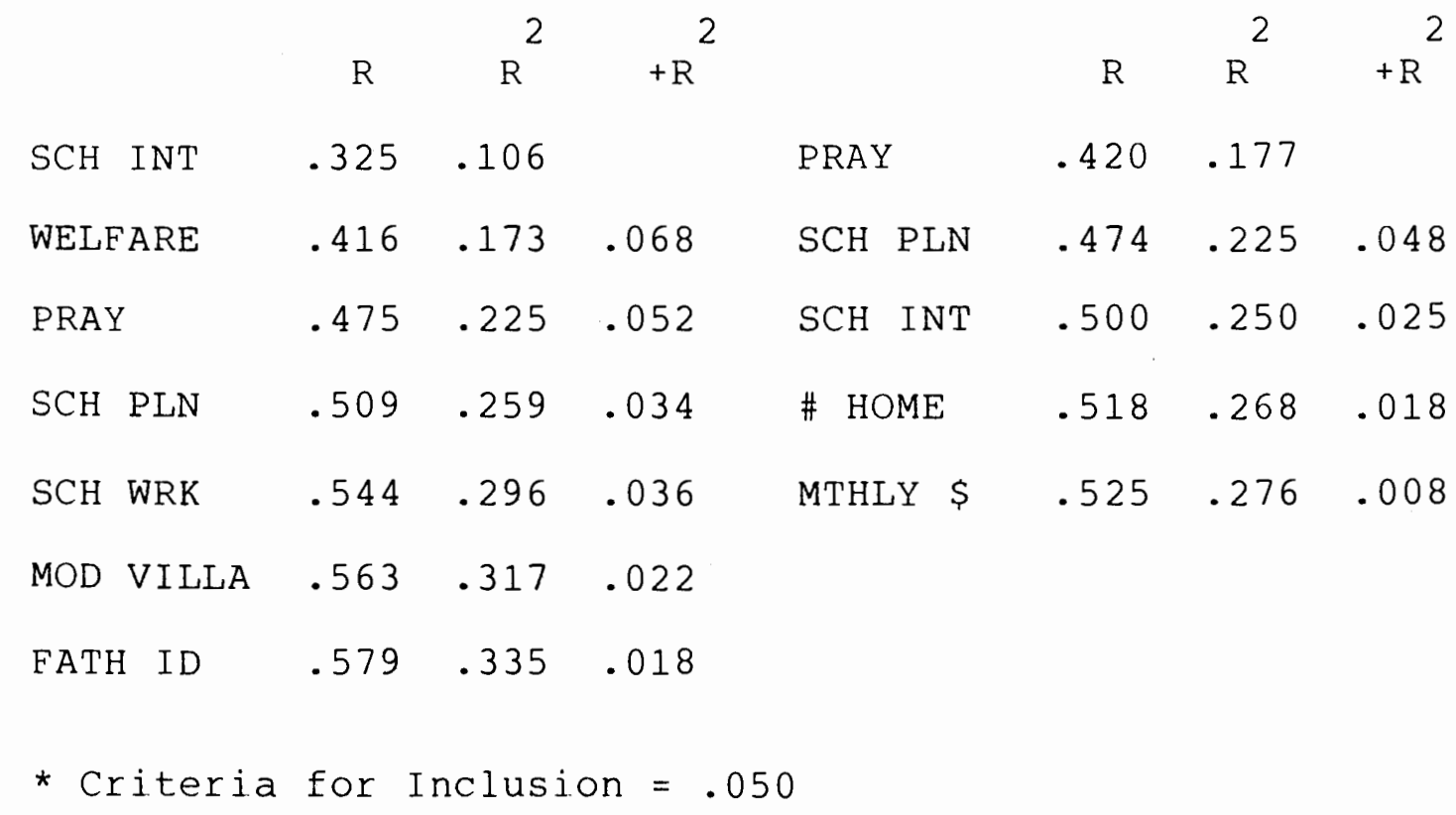

PRAY

SCH PLN

$\mathrm{SCH}$ INT

\# IN HOME

MONTHLY \$ .072

$-.420$ partial
DLNQSUM

zero

order

$-.383$

$-.198$

$-.181$

.144

.103 
Seven variables, explaining $33 \%$ of the variance, were entered into the stepwise regression equation on INCARCERATION. Two of thee variables--school interest and welfare-explained over half of the overall variance. Thus, holding negative school attitudes and coming from a welfare family were strongly associated with being incarcerated for delinquency. Of particular importance is the fact that an important measure of socio-economic status, i.e., welfare recipiency, contributed so significantly to the variance in incarceration. Welfare recipiency was not selected into the stepwise equation on DLNQSUM.

Also of interest is the fact that pray (reflecting strong religious bond and having friends with strong religious bond) was the best predictor of self-report delinquency, alone explaining 18\% of the overall 28\% of the explained variance. While pray was also significantly negatively correlated with incarceration, its contribution to the overall variance here was only $5 \%$

Negative school attitudes (-school interest), a measure of Hirschi's attachment, was highly correlated with both INCARCERATION and DLNQSUM, but here again its differential contribution was substantial. It explained approximately $11 \%$ of the variance in INCARCERATION but not quite $3 \%$ of the variance in DLNQSUM.

Of the five variables entered into the regression equation on DLNQSUM, pray and school plans explained all but 5\% 
of the overall explained variance. Thus, weak religious involvement/belief and weak school commitment emerged as particularly capable predictors of self-report delinquency. Based upon the analysis of the stepwise correlations, it appears that a combination of the best bond and social background variables better predicts INCARCERATION than DLNQSUM. It is also notable that a considerable portion of the variance in both official and unofficial delinquency can be explained by a relatively small number of variables. Some of these variables, of course, represent a scale score derived by combining several items. Nevertheless, a number of items on the original questionnaire simply did not contribute significantly to the variance in self-report or official delinquency. 
STEPWISE MULTIPLE CORRELATIONS: INDEPENDENT VARIABLES BY DELPERS AND DELPROP

Two factors emerged from the factor analysis of the self-report delinquency items. The items with the highest loadings on the first factor were hurt someone badly (V67) and take part in a fight (V69). Thus, this factor emphasized crimes against person. A scale score was derived by combining V67 and V69, creating a new variable labeled DELPERS. The items which loaded most highly on the second factor, taken an expensive car part (V68) and taken a car for a ride (V72), were similarly combined to create another new variable (FV12), labeled DELPROP to reflect its emphasis on property crimes.

Stepwise multiple correlations were run on these factor-derived measures of self-report delinquency in order to identify those independent variables which best explained the variance. The results of these analyses are presented in Table XV. Pray emerged as the single best predictor of both DELPERS and DELPROP, explaining over half of the overall explained variance in each type of delinquency. The second best predictors of DELPERS and DELPROP were school-related items. However, for DELPERS, negative school attachment (-school interest) was the predictive item, whereas, for DELPROP, weak school commitment (-school plans) was reflected. 
TABLE XV

STEPWISE* MULTIPLE CORRELATION

DELPERS

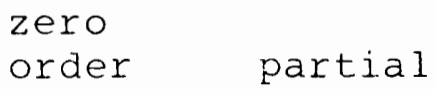

DELPROP

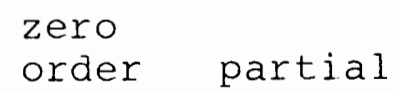

zero
PRAY

$\mathrm{SCH}$ PLN

LIVE MOD

VILLA
.110 .150

FRIENDS $\quad .084 \quad .117$

$$
\begin{aligned}
R & =.40757 \\
2 & R^{2}=.16611
\end{aligned}
$$$$
\mathrm{R}=.38623
$$$$
2
$$$$
R=.14918
$$

$$
R^{2} R^{2}+R^{2} \quad R \quad R^{2}+R^{2}
$$

\begin{tabular}{lccccccc} 
PRAY & .307 & .094 & \multicolumn{3}{c}{ PRAY } & .290 & .084 \\
SCH INT & .358 & .128 & .034 & SCH PLN & .360 & .130 & .045 \\
\# IN HOME & .393 & .154 & .026 & MOD VILLA & .386 & .149 & .020 \\
FRIENDS & .408 & .166 & .012 & & & &
\end{tabular}

* Criteria for Inclusion $=.05$ 
Of theoretical interest is the positive correlation between friends and DELPERS. Feeling that friends are important and that it is important to spend time with friends increases the likelihood of involvement in crimes against the persons. "Friends" did not enter into the stepwise equation on DELPROP.

Also of some interest is the positive relationship between living in a modern villa and DELPROP. While this variable only contributed $2 \%$ to the overall explained variance in DELPROP, the direction of the relationship contradicts arguments that involvement in property crimes results from socio-economic disadvantage. In Saudi Arabian society, living in a modern villa is a measure of socio-economic status.

Overall, the best group of independent variables (determined through the stepwise regression procedure) explained approximately $17 \%$ of the variance in DELPERS and 15\% of the variance in DELPROP. 


\section{SUMMARY AND CONCLUSION}

The basic theoretical assumption in Hirschi's work (1969) is that ties to the conventional social order (referred to by Hirschi as the social bond) operate to control juveniles from becoming involved in delinquent misconduct. Conversely, weak or broken ties increase the likelihood that the juvenile will become involved in delinquency. Hirschi argued further that the social bond consists of four unique elements--attachment, belief, commitment and involvement. Moderate but relatively consistent empirical support has been found for Hirschi's original findings of relationships between delinquency and weak social bond. Findings from a recent study (wiatrowski, et al., 1981), however, indicate that the social control-social bond model is more complex than that elaborated by Hirschi. Specifically, the Wiatrowski, et al. findings suggest that social bond is not a "clean" concept and that other variables (e.g., socio-economic status, school ability) should be added to the social control model.

The present study involved an examination of juvenile delinquency in Saudi Arabia based upon the social control perspective. Using data from self-reports of actual involvement in delinquency and including in the study sample 
populations of incarcerated delinquents as well as "normal" school juveniles, assessments were made of the contribution of the independent variables--social bond and social background items--to the variance in both unofficial and

official delinquency. In addition, comparisons were made of the four groups in the study sample: students attending a public high school, students attending a public junior high school, juveniles incarcerated in an institution for status offenders, and juveniles incarcerated in an institution for serious offenders.

Based upon the self-report data, it appears that delinquency in Saudi Arabia is not limited to an officially identified population. School students as well as incarcerated delinquents reported some involvement in juvenile misconduct. However, the incarcerated youth had higher rates of involvement in all types of delinquency about which the respondents were questioned. The serious offenders were clearly the most heavily involved of all four groups.

There were also differences in the socio-economic status of incarcerated vs. school youth. Overall, the incarcerated youth were more likely than the school youth to be socio-economically disadvantaged. However, this difference was accounted for primarily by the relatively high disadvantage of status offenders. Status offenders were much less likely than the other groups to live in a modern villa or to have family monthly incomes above 3,000 (SR). On the other hand, they were more likely than the others to 
have deceased fathers. Both serious and status offenders had extremely high rates of welfare recipiency $(41 \%$ of each group) compared to the school students (10\% of high school students and $21 \%$ of junior high school students).

While the majority of respondents in all four groups reported having strong social ties with the conventional social order, incarcerated youth were less strongly bonded than the public school students. Youth in the institution for serious offenders had the weakest bond of all four groups. Notable differences were found in the data on school-related bond items. High school students showed the strongest commitment to school, while junior high school students had the highest rate of attachment to school. In contrast, negative school attitudes were most frequently expressed by the serious offenders. Weak religious bond was found much more frequently among the serious offenders than any of the other groups.

The results of a factor analysis of the i.tems assumed to measure social bond called into question Hirschi's contention that the bond consists of four unique elements-attachment, belief, involvement and commitment. Ten factors were identified in a varimax rotated factor structure. Generally, variables with high loadings on each of these factors emphasized one or more elements of the bond within a specific institutional or substantive area, e.g., commitment to school, attachment to parents, attachment to friends, 
involvement in and attachment to school. The first three factors were primarily school-related factors, indicating that school ties are an important dimension of the social bond concept.

Overall, social bond items were capable predictors of delinquency, explaining together $27 \%$ of the variance in incarceration and $26 \%$ of the variance in self-report delinquency. In line with the findings of wiatrowski, et al. , the predictive power of the model was strengthened by including socio-economic variables. However, incarceration for delinquency was better predicted than self-report delinquency by socio-economic factors.

Reflecting the high value placed on religion in saudi Arabian society was the strong negative relationship between religious bond and delinquency. Weak religious bond was the best single predictor of self-report delinquency. "Pray" (the factor-derived variable combining pray every day at the mosque and friends pray every day at the mosque) explained 18\% of the overall explained variance in a stepwise regression analysis on self-report delinquency. Of the "best" preaictors (again determined through a stepwise procedure) of incarceration for delinquency, "pray" was third in the size of the contribution to the explained variance.

School-related items explained a good portion of the variance in both unofficial and official delinquency. Of the "best" independent variables, negative school interest (a measure of school attachment) was the single best 
predictor of incarceration, and low school aspirations (a measure of school commitment) was the second best predictor of self-report delinquency.

Finally, welfare recipiency was highly correlated with incarceration for delinquency, emerging in the stepwise analysis as the second best predictor of this measure of official delinquency. Welfare recipiency did not reach significance for inclusion in the stepwise equation on selfreport delinquency.

The analyses of the data on delinquency in saudi Arabia, then, lend some support to Hirschi's arguments. Social bond items were found to contribute substantially to the variance in both unofficial and official delinquency. Additionally, these data supported Wiatrowski et $\underline{\text { al }}$. in their call for a more complex conceptualization of the social control-social bond model. It should be recognized, however, that correlational analyses, used in this study to determine the contribution of independent variables to juvenile delinquency, do not address the issue of causal order. While Hirschi's theoretical argument is that weak social bond leads to delinquency, it is possible that the causal direction is in the reverse, i.e., delinquency leads to weak social bond. It is also possible, of course, that social bond and delinquency act upon one another in ways that are not yet fully understood and/or that the relationship between the two is affected by other variables. For example, 
the findings from this study suggest that it would be worthwhile to pursue further the role of socio-economic status in the relationship between social bond and delinquency. On the other hand, the fact that an empirical examination of delinquency in Saudi Arabia yielded results which were so compatible with an analytical model based upon American delinquency is a finding of considerable relevance. 
Babbie, Earl. The Practice of Social Research. Belmont: Wadsworth Publishing Co., 1983.

Conklin, John. Sociology An Introduction. New York: MacMillan publishing Co., Dunkhein, 1984.

Cooley, Charles. Human Nature and Social Order. New York: Charles Scribners \& Sons, 1902.

Durkheim, Emile. Suicide: A study in Sociology. trans. by George Simpson and John A. Spaulaing. New York: Free Press, 1897, 1951.

Empey, La Mar. American Delinquency. Homewood: The Dorsey Press, 1978 .

Eve, Raymona. A Study of efficiency and interaction of several theories for explaining rebelliousness among high school student. Journal of Criminal Law and Criminology LXVII (1975), pP. 115-125.

Eve, Raymond and Gary F. Jensen. "Sex Differences in Delinquency: An Examination of Popular Sociological Explanations" Criminology 13 (February) 1976. pp. 427-48.

Gibbons, Don C. Delinquent Behavior. Englewood: PrenticeHall Inc., $1 \overline{981 .}$

Hindelang, Michael. Causes of Delinquency. Social Problems XX (Spring 1973) pp. 471-487.

Hirschi, Travis. Causes of Delinquency. Berkeley: University of California Press, 1969.

Lamb, David. Islamic Law Harsh, Effective for Saudis. The Oregonian newspaper. FEB, 1984 .

Mead, George M. The Genesis of Self and Social Control, International Journal of Ethics XXXV, 1925, pp.251-277.

Ministry of Interior Publications. Riyadh, Saudi Arabia, 1978.

Reckless, walter. The Crime problem. Santa Monica: Goodyear Publishing Co., 1973 .

Ross, Edward. Social Control. New York: MacMillan, 1901. 
Sanger, Richard H. The Arabian Peninsula, Ithica. New York: Cornell university Press, 1954.

Siegel, Larry J. Criminology. St. Paul: West Publishing Co., 1983.

Wiatrowski, Michael D., David B. Griswold and Mary K. Roberts. Social Control Theory and Delinquency. American Sociological Review, Volume 46, 1981, pp. 525-541.

Wiatrowski, Michael D. Social Control Theory and Delinquency. Unpublished, Ph.D. dissertation. Portland state University, 1978 . 
APPENDIX A

QUESTIONNAIRE

1. What is your age?

2. What is your closest idea to your family monthly income?

less than 1,000 Saudi Riyal

1,000 to 2,000 Saudi Riyal

2,000 to 3,000 Saudi Riyal

3,000 to 4,000 Saudi Riyal

5,000 Saudi Riyal or more

3. How close do you feel to your father?

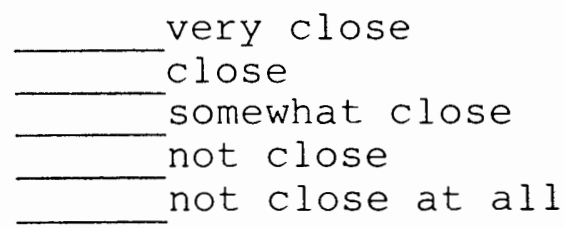

4. How close do you feel to your mother?

very close

close

somewhat close

not close

not close at all

5. How much do you want to be like your father when you are an adult.

very much
I want much
somewhat much
I don't care
I don't want at all

6. How important would you say friends are in your life?

very important

important

somewhat important

not very important

not important at all 
7. How important is it to spend time with your friends? very important important

somewhat important not very important not important at all

8. How do you rate yourself in school ability compared with those in your grade at school? the best good average not real good the worst

9. How close do you come to doing the best work you are able to do in school?

very close
close
somewhat close
not close
not close at all

10. What kind of grades do you get on the average?

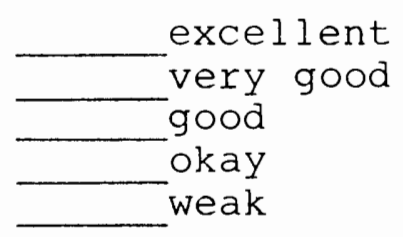


Please check the right answer.

11. I feel satisfied with school because I learn things I want to know.

12. I believe school will help me be a mature adult.

13. School is very boring for me, and I'm not learning what $I$ feel is important.

14. I feel the things I do at school waste my time more than the things I do outside of school.

15. I am studying constantly in oraer to become a well-educated person.

16. My teachers often take an interest in my work.

17. I think my plans for my future job will work out.

18. I will complete high school.

19. It's likely that I will attend college.

20. I have made plans to attend and graduate from college.

21. I am very interested in doing more reading or work than my studies require.

22. It is bad to cheat or have anything to do with a cheating situation, even for a friend.

23. I would help a close friend get by in a tight situation, even though I may have to stretch the truth a bit to do it. 
24. I do things I feel guilty about afterwards.

25. When I do wrong my conscience punished me.

26. In school time I usually spend all evenings with friends for fun and recreation.

27. People in our neighborhood know and care for each other.

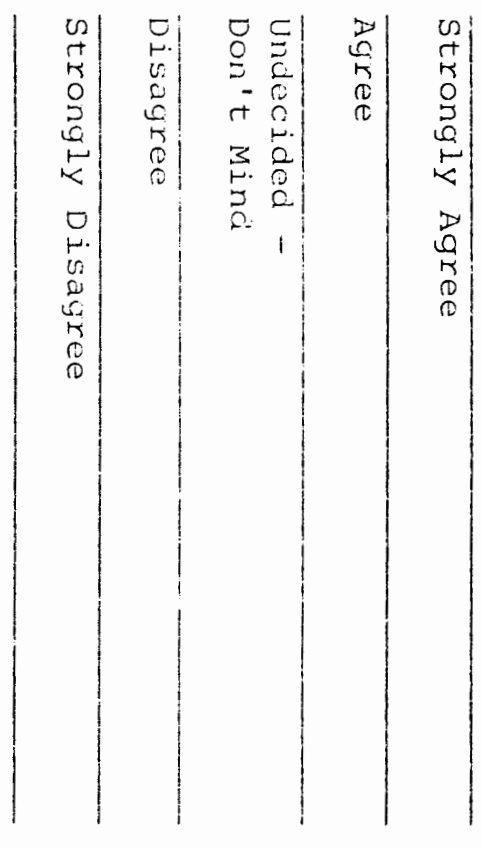

28. How many people altogether, including yourself, live in your home?

29. Do you have your own room at home or do you share it with someone?

I have my own room share i.t with my brothers share it with brothers and/or sisters share with parents share with parents, brothers and sisters share it with adults outside of my family because I don't live at home

30. What kind of home do you live in?

modern villa

traditional home apartment tent adobe home

31. Does your family own or rent your home? own it rent it don't know 
32. Is your father working?

working full-time

working part-time

looking for work

not working because of illness or disability

he is retired

not working for other reasons

he is not living

33. If your father is working, what is his job?

34. Have you decided on a particular kind of job that you aim to do when you have finished your schooling?

\begin{tabular}{l} 
Yes \\
No \\
\hline I don't intend to get a job
\end{tabular}

35. Please write the name of the job that you want to do.

36. Has your family received welfare payments?

no, never

not now but they used to yes, now

37. How much education does your father have?

uneducated

just reads and writes

some high school or iess

graduated from high school

some college or junior college

graduated from a four-year college

father is not living

38. When you are at home, do you pray every time at the Mosque?

yes, all the time

all but the morning prayer

some of them

Friday prayer only

I do it when I have nothing else to do

I don't pray at all 
39. If you don't pray, the reaction of your parents will be: kicked out of home angry and upset they don't mind they don't know they support me in not praying

40. Do all of your frienas pray?

yes, all most of them most don't none of them do I have no friends

Please check the right answer.

41. Do you ever feel that "there is nothing to do?"

42. Have you ever defied your parents openly?

43. Have you ever done a "burning rubber" in a car?

44. Have you ever stayed out at night later than your parents said you should?

45. Have you ever taken something not belonging to you worth under 150 saudi Riyal?

46. Have you ever hurt someone badly enough to need bandages or a doctor?

47. Have you ever taken an expensive part of a car without permission of the owner?

48. Have you ever taken part in a fight where a bunch of your friends are against another bunch? 
49. Have you ever taken something not belonging to you worth over 200 Saudi Riyal?

50. Have you ever used a knife or some other thing like a club to get something from a person?

51. Have you ever taken a car for a ride without the owner's permission?

52. Have you ever banged up something that did not belong to you on purpose?

53. Do you have anything to add? 


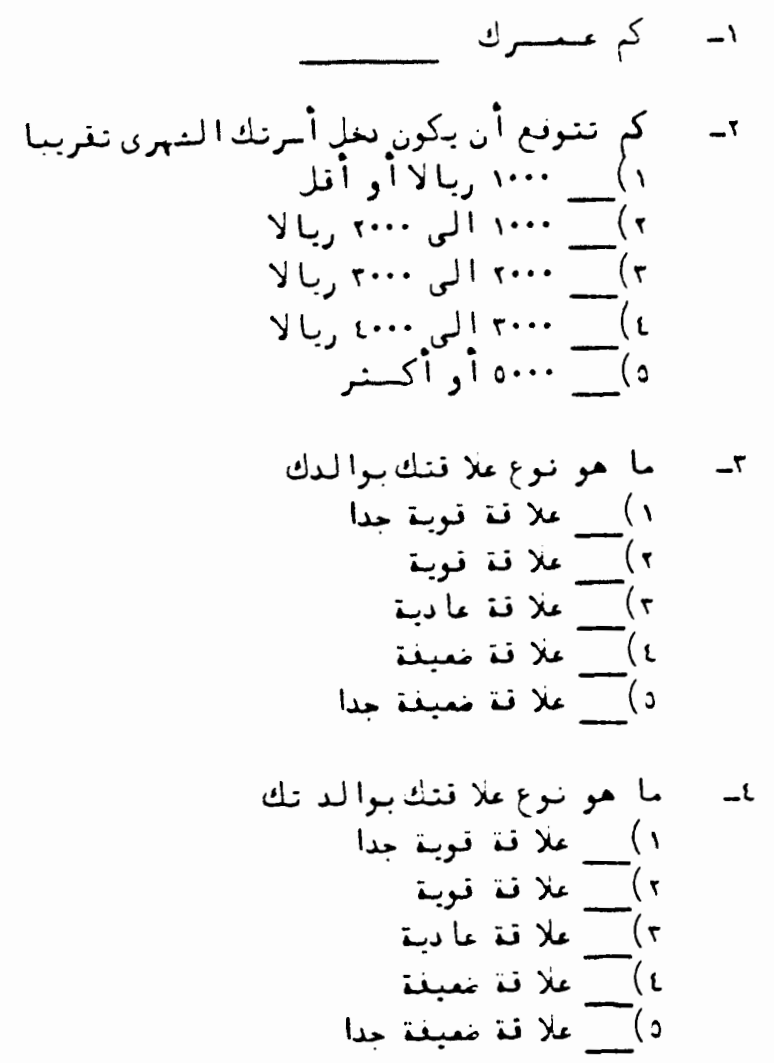

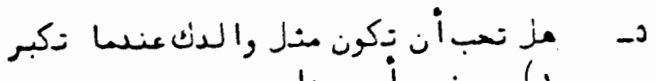

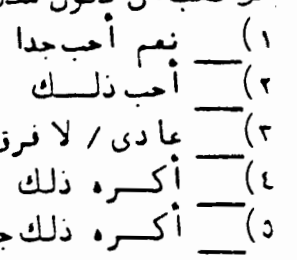

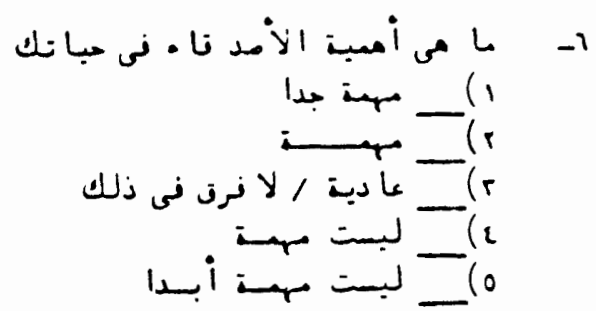




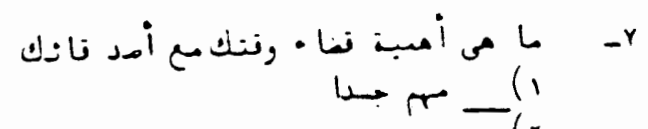

$$
\begin{aligned}
& \text { S }
\end{aligned}
$$

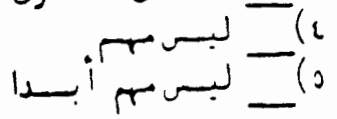

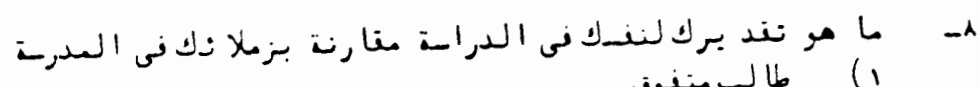

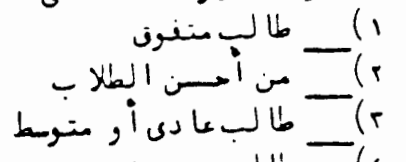

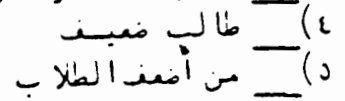

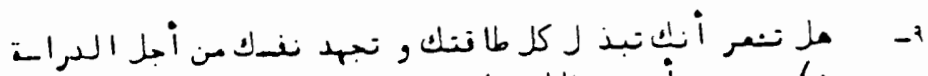
r)

s 1 (2

أìn

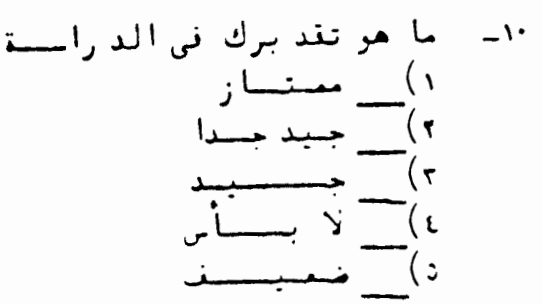




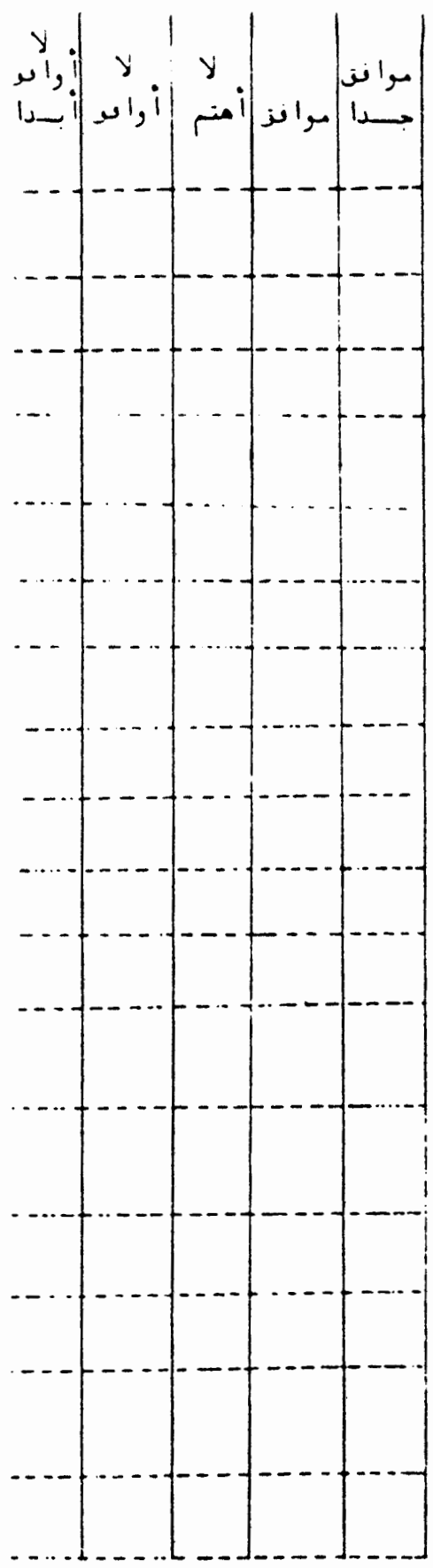

• أرجو ودع علا مة (x) فى الدكان المناسب

أنمر بسادة فى الدراسة لأنى أنملم أيبا. أخبمعرنتها.

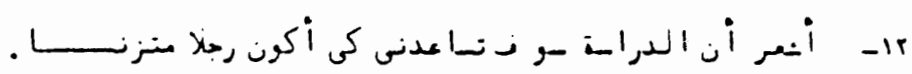

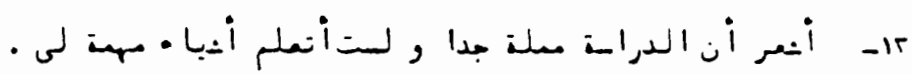

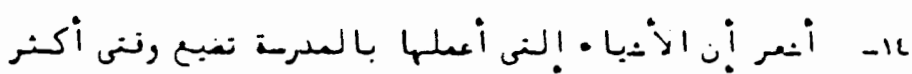

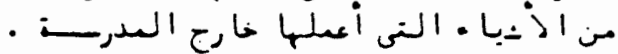

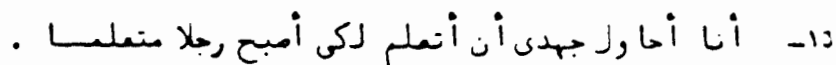

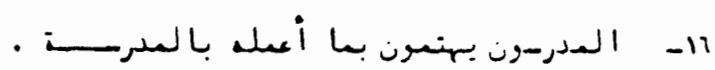

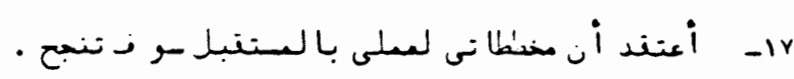

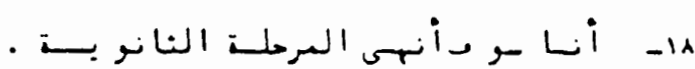

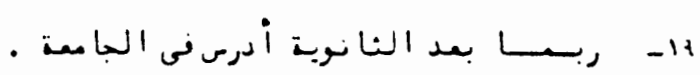

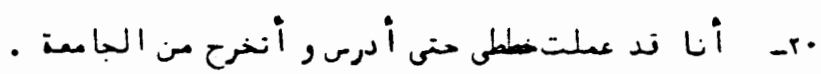

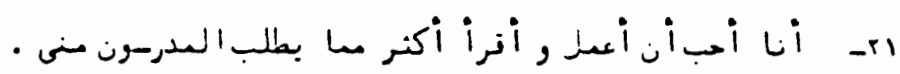

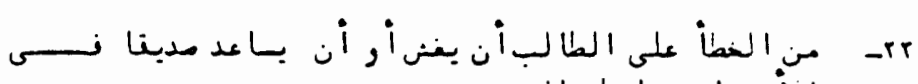

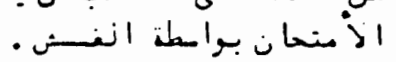

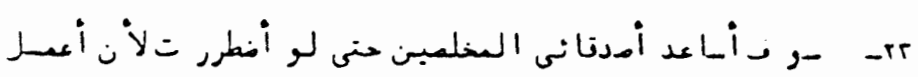

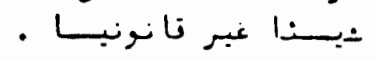

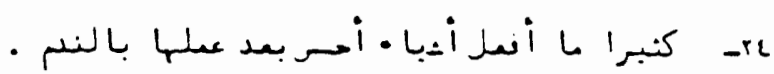

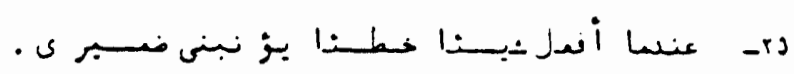

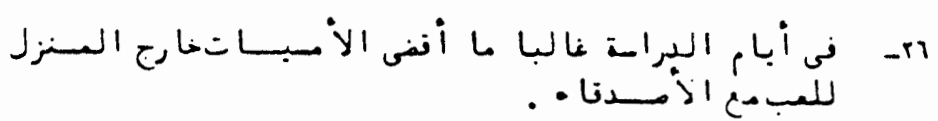

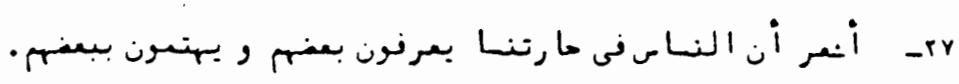




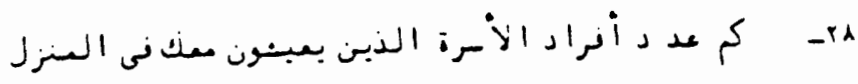

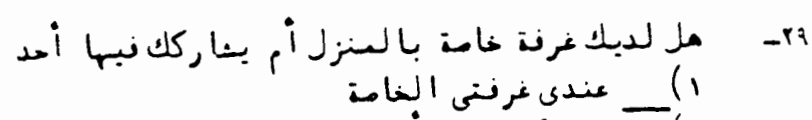

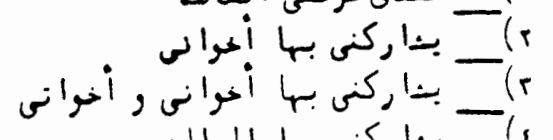

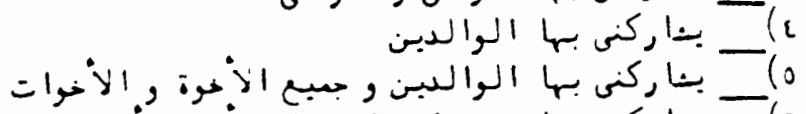

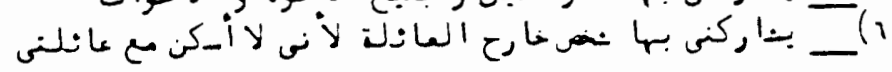

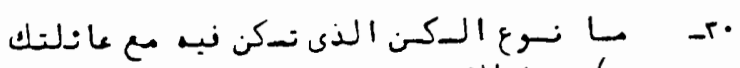

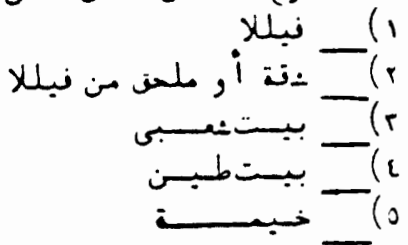

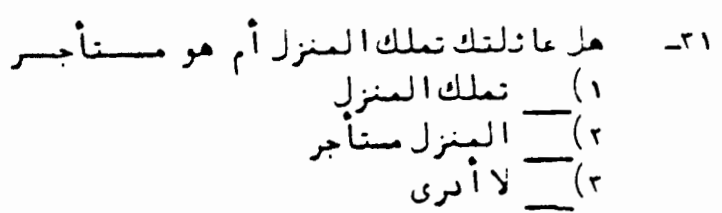

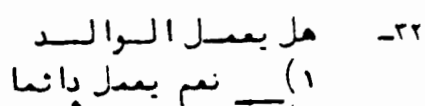

$$
\begin{aligned}
& \text { - r }
\end{aligned}
$$

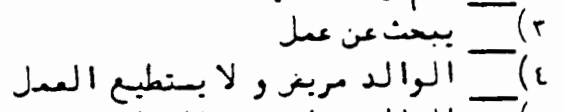

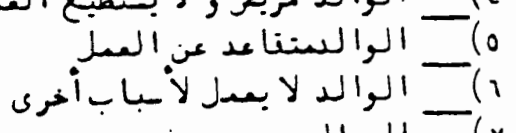

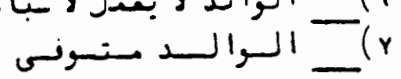

rا 


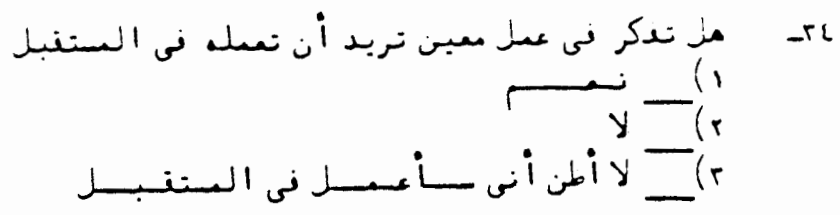
وr- ما مو نوع العمل الذي تريد عله نى المستنبل

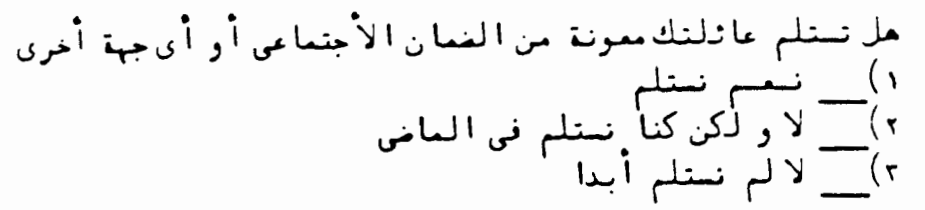

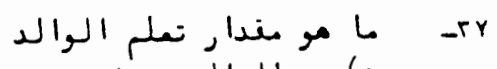

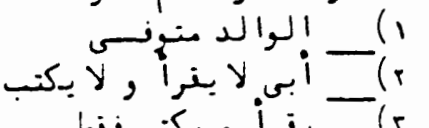

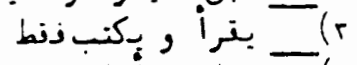

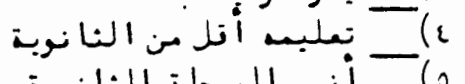

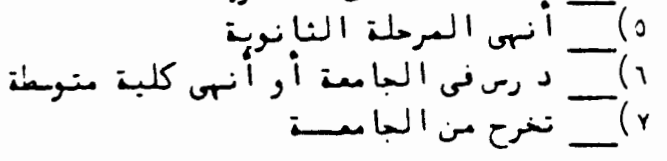

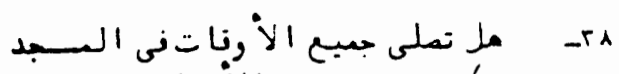

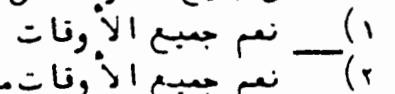

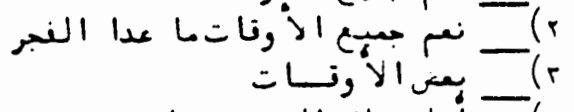

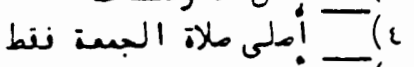

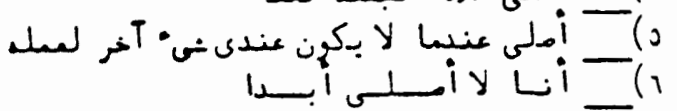




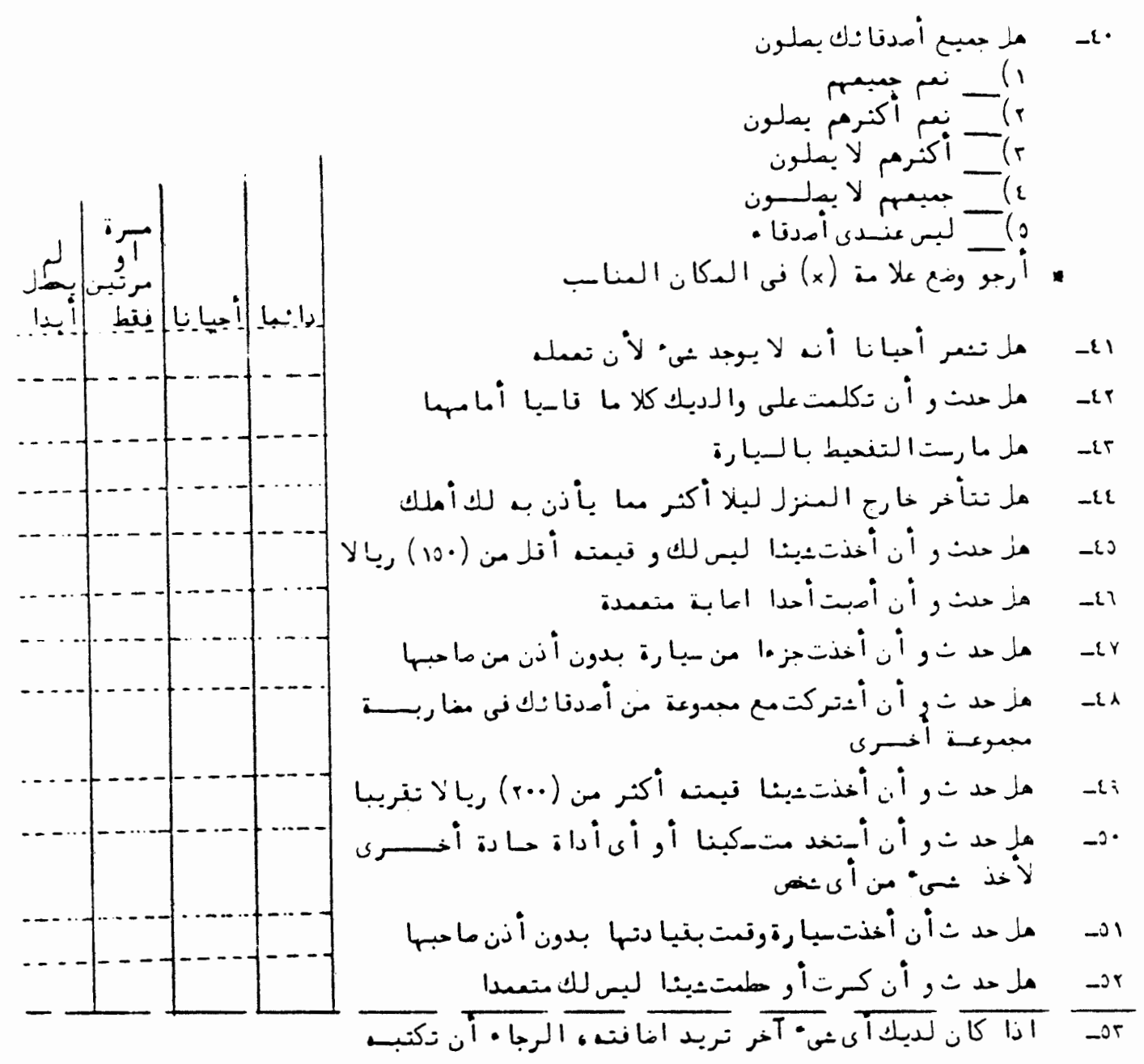


APPENDIX B

NAMES OF VARIABLES

\author{
Bond-Related Items \\ V5 CLOSE TO FATHER? \\ V6 CLOSE TO MOTHER? \\ V7 BE LIKE FATHER? \\ V8 FRIENDS IMPORTANT? \\ V9 TIME W/FRIENDS? \\ V10 SCHOOL ABILITY? \\ V11 DO BEST WORK? \\ V12 KIND OF GRADES? \\ V13 SATISFIED WITH SCHOOL \\ V14 SCHOOL HELP BE MATURE \\ V15 SCHOOL IS BORING \\ V16 SCHOOL WASTE OF TIME \\ V17 STUDY TO BE EDUCATED \\ V18 TEACHERS INTERESTED IN MY WORK \\ V19 PLANS FOR JOB WILL WORK \\ V20 COMPLETE HIGH SCHOOL \\ V21 ATTEND COLLEGE \\ V22 GRADUATE FROM COLLEGE \\ V23 INTEREST IN MORE READING \\ V24 IT IS BAD TO CHEAT
}




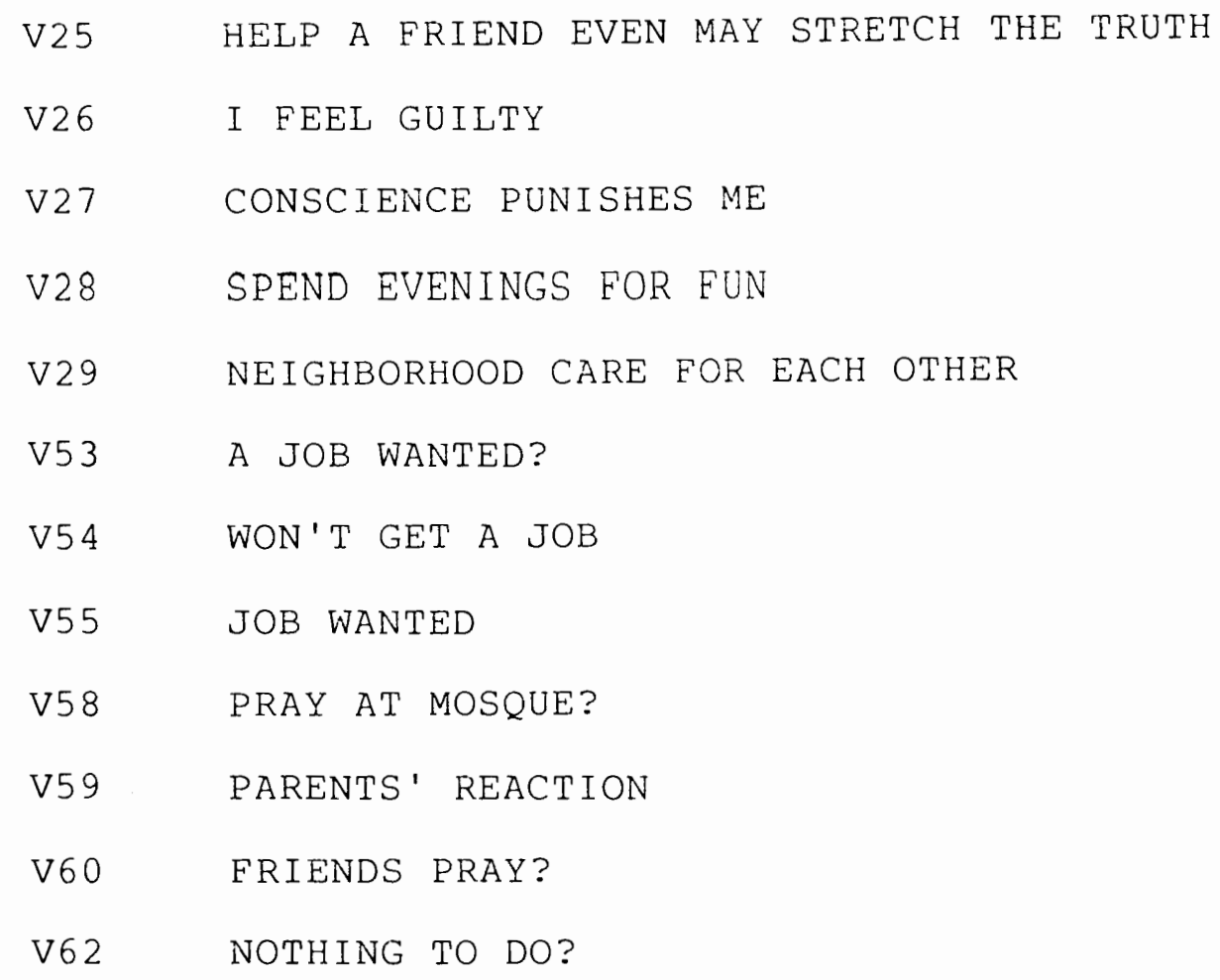

Social Background Items

V3 AGE

V4 MONTHLY INCOME

V30 \# IN HOME

V31 HAVE OWN ROOM

V32 SHARE/BROS

V33 SHARE WITH BROS/SIS

V34 SHARE WITH PARENTS

V35 SHARE WITH PARENTS/BROS/SIS

V36 SHARE WITH OUTSIDE ADULTS

V37 LIVE IN MOD VILLA

V38 LIVE IN TRAD HOME

V39 LIVE IN APART

V40 LIVE IN TENT 
V41 LIVE IN ADOBE

V42 OWN HOME?

V43 RENT HOME

V44 DON'T KNOW

V45 FATHER W'K FULL TIME

V46 FATHER WK PART TIME

V47 FATHER LOOKING FOR WORK

V48 EATHER ILL

V49 FATHER RETIRED

V50 EATHER NOT WKING--OTHER

V51 FATHER NOT LIVING

52 FATHER'S JOB

V56 RECEIVE WELFARE?

V57 FATHER'S EDUC

V61 HAVE NO FRIENDS

Delinquent Acts Items

V63 DEFIED PARENTS OPENLY

V64 BURNING RUBBER

V65 STAYED OUT LATE

V66 TAKEN SOMETHING LESS THAN 150 SAUDI RIYAL

V67 HURT SOMEONE BADLY

V68 TAKEN EXPENSIVE PART OF A CAR

V69 TAKEN PART IN A FIGHT

V70 TAKEN SOMETHING MORE THAN 200 SAUDI RIYAL

V71 USE A KNIFE OR A CLUB

V72 TAKEN A CAR FOR A RIDE 
APPENDIX C

LIST OF FACTOR VARIABLES

FV1 SCHOOL PLAN (complete high school, attend college, attend and graduate from college)

FV2 SCHOOL WORK (do best work, satisfied with school, study to be educated, teachers interested in my work, plan for future job will work, interested in doing more reading and school work)

FV3 SCHOOL INTEREST (school boring, school waste of time)

FV4 SCHOOL ABILITY (school ability compared to others in my grade, kind of grades)

FV5 PRAY (pray at mosque, friends pray at mosque)

FV6 CLOSE TO PARENTS (close to father, close to mother)

FV7 FATHER IDENTIFICATION (close to father, want to be like father)

FV8 FRIENDS (friends important, time with friends important)

FV9 JOB WANTED (decided on future job, intend to get a job)

FV10 BELIEF (bad to cheat, feel guilty, conscience punishes me)

FV11 DELPERS (hurt someone badiy, take part in a fight)

FV12 DELPROP (take expensive part of car, take care for a ride) 